\title{
2. LOWER CRETACEOUS VOLCANIC ROCKS ON CONTINENTAL MARGINS AND THEIR RELATIONSHIP TO THE KERGUELEN PLATEAU1
}

\author{
M. Storey, ${ }^{2}$ R. W. Kent, ${ }^{2}$ A. D. Saunders, ${ }^{2}$ V. J. Salters,${ }^{3}$ J. Hergt, ${ }^{4}$ H. Whitechurch,${ }^{5}$ J. H. Sevigny, ${ }^{6}$ \\ M. F. Thirlwall, ${ }^{7}$ P. Leat,${ }^{8}$ N. C. Ghose,${ }^{9}$ and M. Gifford ${ }^{10}$
}

\begin{abstract}
Widespread Lower Cretaceous magmatism occurred along the Indian-Australian/Antarctic margins, and in the juvenile Indian Ocean, during the rifting of eastern Gondwana. The formation of this magmatic province probably began around 120-130 Ma with the eruption of basalts on the Naturaliste Plateau and at Bunbury, western Australia. On the northeast margin of India, activity began around $117 \mathrm{Ma}$ with the Rajmahal continental basalts and associated lamprophyre intrusions. The formation of the Kerguelen Plateau in the Indian Ocean began no later than $114 \mathrm{Ma}$. Ultramafic lamprophyres (alnoites) were emplaced in the Prince Charles Mountains near the Antarctic continental margin at $\sim 110 \mathrm{Ma}$. These events are considered to be related to a major mantle plume, the remnant of which is situated beneath the region of Kerguelen and Heard islands at the present day.

Geochemical data are presented for each of these volcanic suites and are indicative of complex interactions between asthenosphere-derived magmas and the continental lithosphere. Kerguelen Plateau basalts have $\mathrm{Sr}$ and $\mathrm{Nd}$ isotopic compositions lying outside the field for Indian Ocean mid-ocean ridge basalts (MORB) but, with the exception of Site 738 at the southern end of the plateau, within the range of more recent hotspot basalts from Kerguelen and Heard Islands. However, a number of the plateau tholeiites are characterized by lower ${ }^{206} \mathrm{~Pb} /{ }^{204} \mathrm{~Pb}$ ratios than are basalts from Kerguelen Island, and many also have anomalously high $\mathrm{La} / \mathrm{Nb}$ ratios. These features suggest that the source of the Kerguelen Plateau basalts suffered contamination by components derived from the Gondwana continental lithosphere. An extreme expression of this lithospheric signature is shown by a tholeiite from Site 738, suggesting that the southernmost part of the Kerguelen Plateau may be underlain by continental crust.

The Rajmahal tholeiites mostly fall into two distinct geochemical groups. Some Group I tholeites have $\mathrm{Sr}$ and $\mathrm{Nd}$ isotopic compositions and incompatible element abundances, similar to Kerguelen Plateau tholeiites from Sites 749 and 750 , indicating that the Kerguelen-Heard mantle plume may have directly furnished Rajmahal volcanism. However, their elevated ${ }^{207} \mathrm{~Pb} /{ }^{204} \mathrm{~Pb}$ ratios indicate that these magmas did not totally escape contamination by continental lithosphere. In contrast to the Group I tholeiites, significant contamination is suggested for Group II Rajmahal tholeiites, on the basis of incompatible element abundances and isotopic compositions.

The Naturaliste Plateau and the Bunbury Basalt samples show varying degrees of enrichment in incompatible elements over normal MORB. The Naturaliste Plateau samples (and Bunbury Basalt) have high La/Nb ratios, a feature not inconsistent with the notion that the plateau may consist of stretched continental lithosphere, near the ocean-continent divide.
\end{abstract}

\section{INTRODUCTION}

Kerguelen Plateau and Broken Ridge, which were originally contiguous, have an estimated combined crustal volume of approximately $57 \times 10^{6} \mathrm{~km}^{3}$, comparable to the Ontong Java Plateau in the Pacific (Schubert and Sandwell, 1989). The formation of this major volcanic edifice in the juvenile Lower Cretaceous Indian Ocean was accompanied by magmatism

\footnotetext{
${ }^{1}$ Wise, S. W., Jr., Schlich, R., et al., 1992. Proc. ODP, Sci. Results, 120: College Station, TX (Ocean Drilling Program).

2 Department of Geology, University of Leicester, University Road, Leicester LE1 7RH, United Kingdom.

${ }^{3}$ Lamont-Doherty Geological Observatory, Columbia University, Palisades, NY 10562, U.S.A.

${ }^{4}$ Department of Earth Sciences, The Open University, Walton Hall, Milton Keynes MK7 6AA, United Kingdom.

5 Ecole et Observatoire de Physique du Globe, 5 rue Descartes, 67084 Strasbourg, France.

${ }^{6}$ Department of Geology and Geophysics, University of Calgary, 2500 University Drive N.W., Calgary, Alberta T2N 1N4, Canada.

${ }^{7}$ Department of Geology, Royal Holloway and Bedford New College, Egham Hill, Egham, Surrey TW20 OEX, United Kingdom.

${ }^{8}$ Department of Geological Sciences, University of Durham, Science Laboratories, South Road, Durham DH1 3LE, United Kingdom (present address: British Antarctic Survey, High Cross, Cambridge CB3 OET, United Kingdom).

9 Department of Geology, Patna University, Patna-800005, India.

${ }^{10} 5 / 1$ Dorset Street, Busselton, West Australia 6280, Australia.
}

along the continental margins of eastern Gondwana, proximal to the plateau. Specifically, continental basalts were erupted in northeastern India in the Rajmahal region and in western Australia at Bunbury and, offshore, on the Naturaliste Plateau. Lamprophyre intrusions occur in India and Antarctica. These occurrences are summarized in Figure 1.

One of the main objectives of Ocean Drilling Program (ODP) Legs 119 and 120 was to recover basement material that would help test the various hypotheses that have been proposed for the origin of the Kerguelen Plateau. However, any model for the origin of the plateau should also account for the associated continental magmatism. Previously proposed models for the origin of the Kerguelen Plateau include:

1. Continental fragment: Dietz and Holden (1970) suggested that the plateau contains rifted continental crust, a remnant of the Gondwana supercontinent. Schlich et al. (1971) considered the sedimentary section of the northern plateau to have continental affinities whereas Ramsay et al. (1986) suggested that the Southern Kerguelen Plateau, based on the granitic material and metasediments in free-fall grab samples, contains continental crust.

2. Uplifted oceanic crust: Houtz et al. (1977) suggested that the Kerguelen Plateau was, in part, a remnant of Cretaceous ocean basin crust that formed to the west of Australia during the separation of India from Australia-Antarctica. 


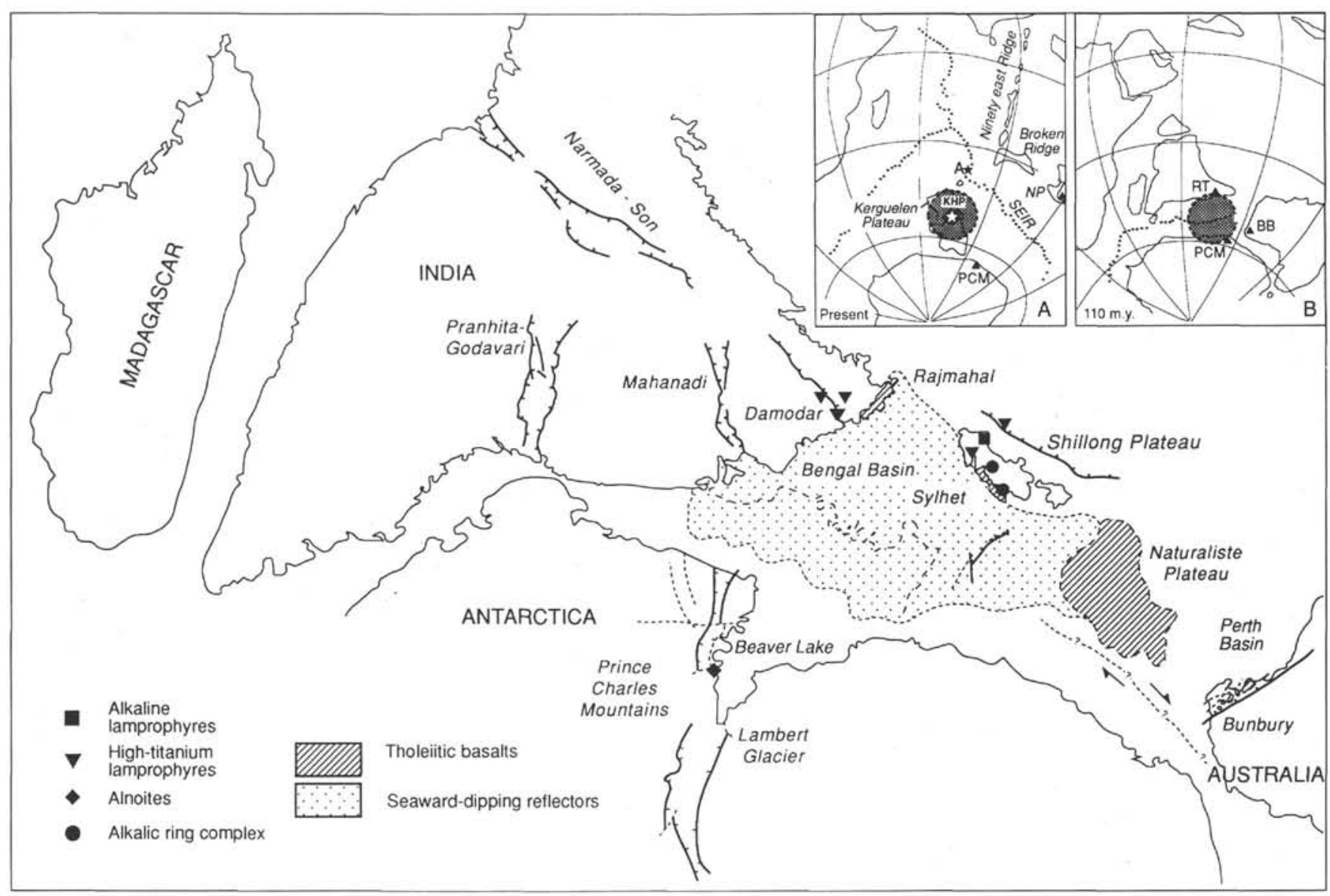

Figure 1. Reconstruction of eastern Gondwana at ca. 120 Ma showing the location and nature of continental Lower Cretaceous volcanism immediately before, or contemporaneous with, the formation of the Kerguelen Plateau at ca. 110-115 Ma (modified from Kent, 1991). Also shown are the position of rift zones that acted as major drainage pathways for up to $150 \mathrm{~m}$.y. before the beginning of igneous activity (Kent, 1991). Inset shows (A) the present-day location of the Kerguelen-Heard plume (KHP) between Kerguelen and Heard islands and (B) its position at $110 \mathrm{Ma}$, at the time of formation of the Kerguelen Plateau. RT = Rajmahal Traps; BB = Bunbury Basalt; and PCM = Prince Charles Mountains. It has been suggested (e.g., Davies et al., 1989; Storey et al., 1989) that this entire magmatic province may be attributable to the KHP, which has more recently produced Dupal-type oceanic basalts (Hart, 1984) on Kerguelen and Heard islands in the southern Indian Ocean (Storey et al., 1988; Barling and Goldstein, 1990; Gautier et al., 1990).

3. Hotspot related: A hotspot or mantle plume origin for the Kerguelen Plateau has been suggested by many authors based on plate reconstructions and geochemistry (e.g., Luyendyck and Rennick, 1977; Duncan, 1978; Peirce, 1978; Morgan, 1981; Storey et al., 1989; Weis et al., 1989; Davies et al., 1989).

This paper represents a preliminary report of work in progress in which we review the setting of the Kerguelen Plateau and associated continental volcanism, present new major and trace element data for each of the volcanic occurrences, and examine the data in terms of the above models.

\section{GEOLOGICAL SETTING}

\section{Kerguelen Plateau}

The Kerguelen Plateau, located on the Antarctic Plate between $46^{\circ}$ and $64^{\circ} \mathrm{S}$, is one of the most important physiographic features on the Indian Ocean floor (Fig. 2). It runs north-northwest for approximately $2300 \mathrm{~km}$, is about $500 \mathrm{~km}$ wide, and rises over $3 \mathrm{~km}$ above the surrounding ocean floor. It is separated from the Antarctic continent by the 100km-wide, 3500-m-deep Princess Elizabeth trough. Seafloor spreading at the Southeast Indian Ridge (SEIR) separated the Kerguelen Plateau and Broken Ridge approximately 45-42 Ma ago (e.g., Houtz et al., 1977; Munschy and Schlich, 1987).

The Kerguelen Plateau has been divided into northern and southern sectors by Schlich (1975) and Houtz et al. (1977). The northern part generally lies in water depths of less than $1000 \mathrm{~m}$ and contains the Eocene to Quaternary volcanic islands of Kerguelen, McDonald, and Heard. The boundary between the northern and southern sectors of the plateau lies immediately south of Heard Island. The transition zone exhibits a complex bathymetry with a large west-trending spur, the Elan Bank, extending from the main plateau over a distance of some $600 \mathrm{~km}$. The southern portion of the plateau is generally deeper, with water depths between 1000 and 3000 $\mathrm{m}$, and has a more subdued topography. It consists of a broad anticlinal arch affected by multiple stages of normal faulting that result in horst and graben development (e.g., Coffin et al., 1986). The axis of this arch is marked by the $77^{\circ} \mathrm{E}$ Graben.

Seismic refraction studies on and in the vicinity of the Kerguelen Archipelago by Recq et al. (1983), Recq and Charvis (1986), and Recq et al. (1990) suggest a crustal thickness of between 15 and $23 \mathrm{~km}$ for this part of the plateau. 


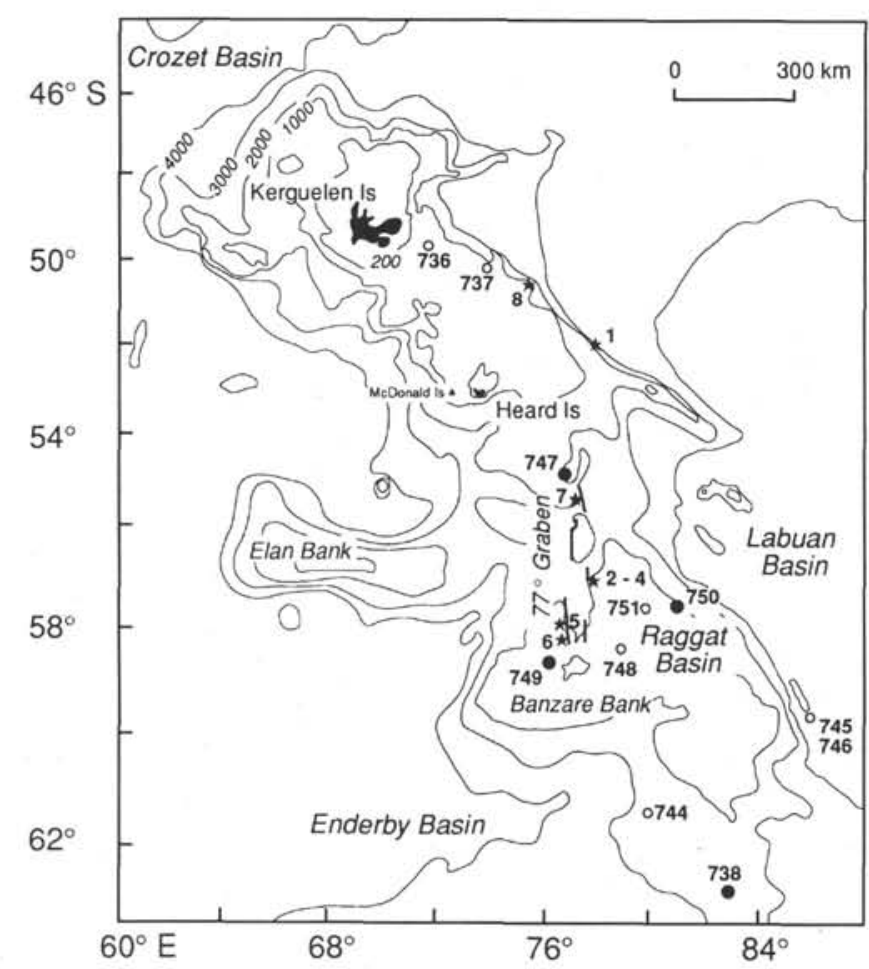

Figure 2. Bathymetric map (in meters) of the Kerguelen Plateau showing the location of ODP drill sites (circles; filled circles denote basement sites) and MD48 dredge stations (stars).

These authors note that the seismic velocity vs. depth profile is typical of oceanic islands. Houtz et al. (1977) inferred a crustal thickness of 20-23 km for the Southern Kerguelen Plateau based on the gravity data.

According to Schlich (1982), the oldest magnetic anomaly bordering the plateau is 34 (equivalent to $84 \mathrm{Ma}$, following the time scale of Kent and Gradstein, 1985), which occurs in the Crozet Basin. However, a recent revision of the magnetic profiles in the Enderby Basin on the southwestern margin of the plateau $(\mathrm{Li}, 1988)$ has indicated the presence of magnetic anomalies M1-M7 (122-128 Ma).

The first drill samples from the Kerguelen Plateau basement were obtained on the central and southern parts of the plateau during ODP Legs 119 and 120 (Fig. 2). In addition, dredge samples (including basalt) from the $77^{\circ} \mathrm{E}$ Graben and the northern part of the plateau were obtained by the Marion Dufresne in 1986 (Cruise MD48; Leclaire et al., 1987). Detailed descriptions of the Cruise MD48 dredge samples and the Leg 119 and 120 cores are given by Bassias et al. (1987), Barron, Larsen, et al. (1989), and Schlich, Wise, et al. (1989), respectively. Some of the Kerguelen Plateau basement basalts appear to have been erupted in a subaerial environment, as evidenced by the presence of oxidized flow tops at Site 747 and overlying nonmarine sediments, of probable Albian age, at Site 750 (Schlich, Wise, et al., 1989). The age of the overlying sediment at the remaining sites is pre-Turonian (limestone) at Site 738, lower Santonian (nannofossil chalk) at Site 747, and early Eocene (nannofossil ooze) at Site 749. In addition, at Site 748 , some $150-200 \mathrm{~m}$ above the seismic basement, a highly altered alkali-basalt flow was drilled, overlain by an undated conglomerate and then by upper Albian-Turonian sandstones (Schlich, Wise, et al., 1989).

Radiometric dating of the Kerguelen Plateau basement has so far been restricted to a few samples from the central- southern parts of the plateau (Leclaire et al, 1987; Whitechurch et al., this volume). Whole-rock dating on the leastaltered Leg 120 basalts give ${ }^{40} \mathrm{Ar}{ }^{39} \mathrm{Ar}$ "plateau ages" of 109.2 $\pm 0.7 \mathrm{Ma}$ for Site 749 located on the Banzare Bank and 118.2 $\pm 5 \mathrm{Ma}$ for Site 750 in the Raggatt Basin (Whitechurch et al., this volume). The Leg 120 results show a close correspondence to a plagioclase $\mathrm{K}-\mathrm{Ar}$ age of $114 \pm 1 \mathrm{Ma}$ from a dredged tholeiite (dredge station 5) on the $77^{\circ} \mathrm{E}$ Graben (Leclaire et al., 1987). However, all of the three dated samples are within 400 $\mathrm{km}$ of each other (Fig. 2). These dates, when coupled with the age of the oldest magnetic anomalies in the Crozet Basin, suggest that the plateau may span at least $30 \mathrm{~m} . \mathrm{y}$. Further sampling and dating studies are required, particularly on the northern and southern extremities of the plateau.

\section{Naturaliste Plateau and Bunbury Basalt}

The Naturaliste Plateau (Fig. 3) is a submarine topographic high rising about $2500 \mathrm{~m}$ above the surrounding ocean floor at the southwestern corner of continental Australia, and separated from it by a deep channel, the Naturaliste Trough (Jongsma and Petkovic, 1977). The plateau runs approximately $400 \mathrm{~km}$ east-west and $250 \mathrm{~km}$ north-south. It dips slightly to the north with steep flanks to the south and west. On the northern flank a regular continental rise apron has developed east of $111^{\circ} \mathrm{E}$, continuous with that of the margin of Western Australia, but the western part of the northern flank is steep. To the northwest, the Naturaliste Plateau abuts oceanic crust of Lower Cretaceous age M4 (126.5 Ma) whereas M11 (132.5 Ma) represents the onset of seafloor spreading in the Perth Basin.

The Deep Sea Drilling Program drilled on the Naturaliste Plateau at Sites 258 (Leg 26) and 264 (Leg 28). Site 258 consisted of some $525 \mathrm{~m}$ of marine Cenozoic and Cretaceous sediments. The lowest part of the section consisted of glauconitic sandstone and silty clay, overlain by $251 \mathrm{~m}$ of midAlbian to Cenomanian ferruginous clays. Most of the detrital constituents of this lower part were probably derived from the erosion of basaltic volcanic rocks, the source probably being an elevated, subaerially exposed part of the plateau (Davies et al., 1974). At Site 264, $171 \mathrm{~m}$ of marine carbonate sediments were drilled, ranging in age from Holocene to Santonian. The drill bottomed after a further $35 \mathrm{~m}$ of altered, nonfossiliferous volcaniclastic conglomerate, estimated by Hayes, Frakes, et al. (1975) to be Cenomanian or older in age. Coleman et al. (1982) consider that the top of this conglomerate corresponds to a prominent reflector that Jongsma and Petkovic (1977) described and which they were able to trace over much of the subsurface of the plateau. Dredge samples recovered from the steep northwestern flanks of the plateau by the Eltanin in 1972 were reported by Heezen and Tharp (1973) as containing rocks of continental origin, although reexamination of the dredge haul by Coleman et al. (1982) revealed that the rock clasts were actually altered tholeiitic basalts.

The Bunbury Basalt represents a possible onland correlative to the Naturaliste Plateau. It consists of a few thick tholeiitic flows that crop out over $140 \mathrm{~km}$ of the southern portion of the Perth basin (Fig. 3). K-Ar ages for the Bunbury Basalt range from 88 to $105 \mathrm{Ma}$ (McDougall and Wellman, 1976). However, a dolerite from the Perth Basin has been dated at $136 \pm 3 \mathrm{Ma}$ (Playford et al., 1976), and a similar age has been inferred for the Bunbury basalt (e.g., Davies et al., 1989). More precise dating of both the Naturaliste Plateau and the Bunbury Basalt are required.

\section{Rajmahal Volcanic Formation}

The Rajmahal Volcanic Formation is exposed on the continental margin of northeast India, cropping out over an 


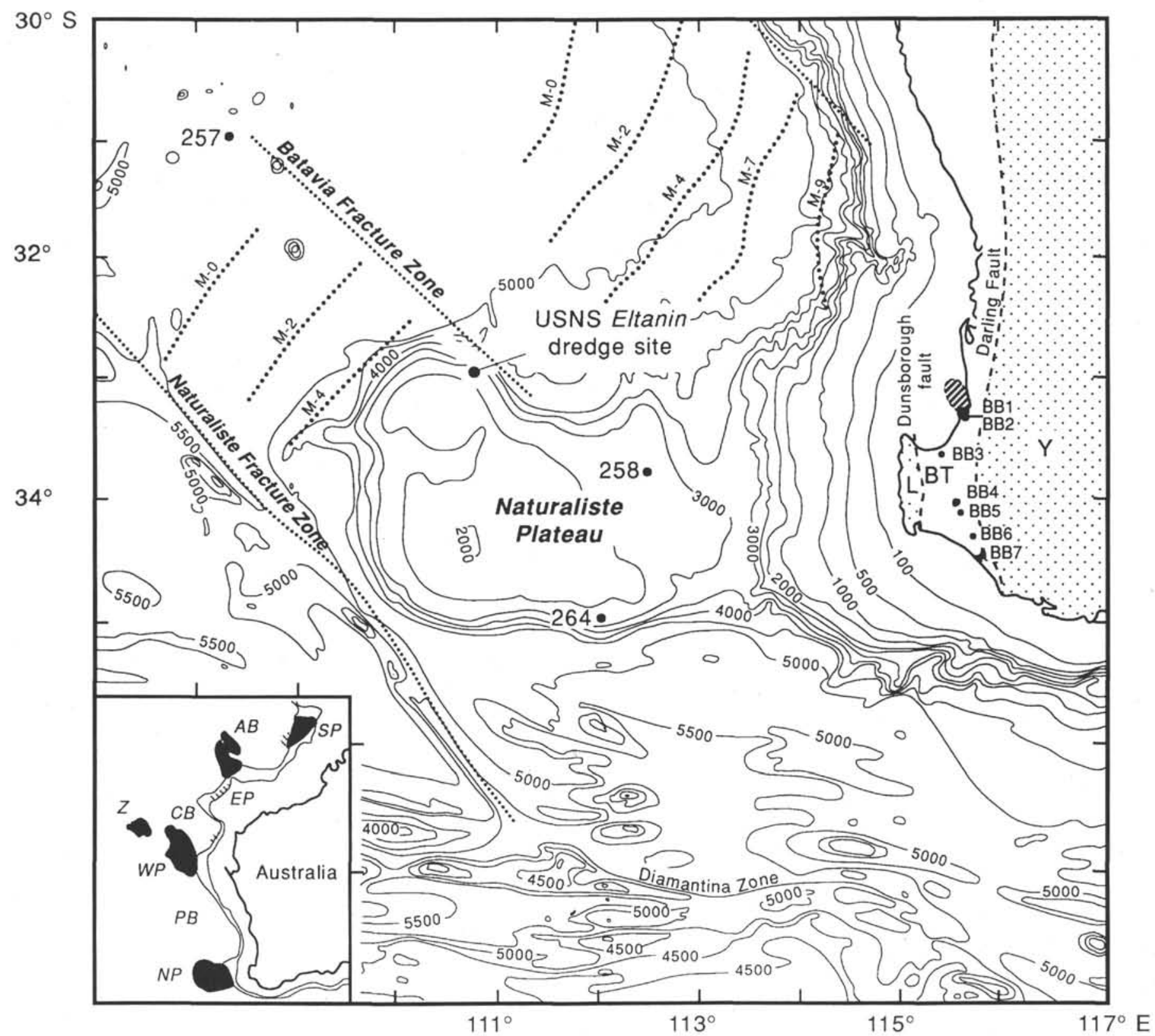

Figure 3. Bathymetric map (in meters) of the southwest Australian continental margin (after Coleman et al., 1982) showing the location of the Naturaliste Plateau, major fracture zones, seafloor magnetic anomalies, and the location of Eltanin dredge and Bunbury Basalt samples. Also shown are DSDP Sites 257, 258, and 264. Y = Yilgarn Block (Archean), L = Leeuwin Block (Proterozoic), and BT = Bunbury trough. Inset shows location of other major plateaus and basins on the west Australian continental margin: NP $=$ Naturaliste Plateau, PB $=$ Perth Basin, WP $=$ Wallaby Plateau, $\mathrm{Z}=$ Zenith Seamounts, $\mathrm{CB}=$ Cuvier Basin, EP $=$ Exmouth Plateau, AB = Argo Basin, and SP $=$ Scott Plateau.

area of around $4,300 \mathrm{~km}^{2}$ in the Rajmahal Hills, Bihar (Fig. 4). The formation consists dominantly of quartz-normative tholeiites, with minor olivine-basalts and basaltic andesites, totaling some $200-300 \mathrm{~m}$ in thickness. This wedge of subaerial volcanics overlies a thin sequence of Early Permian to Early Cretaceous sediments (the Gondwana Supergroup), in turn resting on a high-grade Precambrian basement complex (the Chotanagpur mobile belt). The volcanics are interbedded with thin sedimentary or volcaniclastic horizons, containing locally abundant Lower Cretaceous plant fragments (Sengupta, 1988). Dating of the basalts by ${ }^{40} \mathrm{Ar} /{ }^{39} \mathrm{Ar}$ (Baksi, 1989) also supports a Early Cretaceous age of $117 \pm 1 \mathrm{Ma}$.
These rocks are believed to be cogenetic with a suite of tholeiites and alkali basalts exposed along the Dauki lineament near Sylhet, Meghalaya. In this area, a $60 \times 40 \mathrm{~km}$ strip of lavas, some $500-600 \mathrm{~m}$ thick (?), has been documented by Talukdar (1967) and Talukdar and Murthy (1970). The volcanic succession comprises alternating tholeiitic and felsic pyroclastic/rhyolite units, overlain by nepheline tephrites, dipping $19^{\circ}-25^{\circ}$ toward the southeast. The sequence is cut by a basic dyke swarm, the extent and nature of which is uncertain at present. Early Cretaceous alkaline complexes also occur in this region (Chattopadhyay and Hashimi, 1984). 


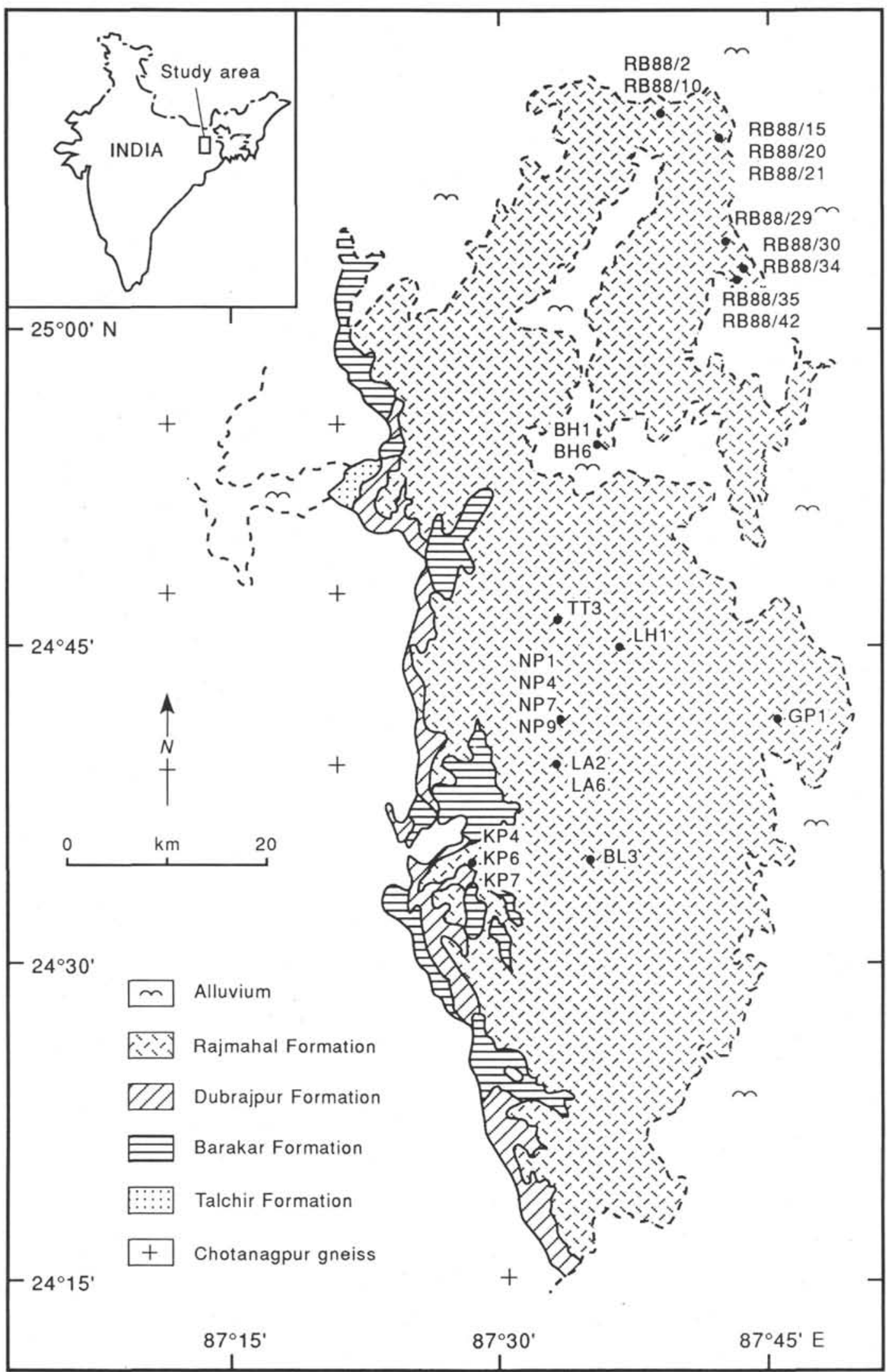

Figure 4. Simplified geological map of the Rajmahal region showing the locations of the basalts analyzed. 
During the 1950s, the subsurface geology of the Bengal Basin was the focus of an integrated hydrocarbon prospect by the Standard Vacuum Oil Company (Mobil/Esso). Seismic reflection profiles and borehole data revealed the presence of a seaward-dipping reflector sequence on the continental margin, comprising a thin wedge of mafic flows (Biswas, 1963; Sengupta, 1966). These flows form the tops of tilted fault blocks, similar in structural style to those on the opposing continental margin of southwest Australia (Marshall and Lee, 1989), and suggestive of episodic extension and, by inference, transtension. Kent (1991) relates these features to episodic doming and extension of eastern Gondwana lithosphere from Early Permian to Early Cretaceous times.

\section{Damodar Valley and Darjeeling Lamprophyres}

Recent work by Sarkar et al. (1980) and Paul and Potts (1981) provided the first geochemical and geochronological data on Indian Cretaceous lamprophyres. These rocks intrude sediments of the Gondwana Supergroup in the Damodar and Darjeeling coal fields and are also found along lineament zones in the Proterozoic metamorphic complexes of the Shillong Plateau (Fig. 1). They consist of both alkaline and ultramafic varieties, emplaced in the form of horizontal cylinders or, more rarely, as thin dykes and sills. $\mathrm{K}-\mathrm{Ar}$ ages on biotite phenocrysts and whole-rock samples range from 121 to 105 Ma (Sarkar et al., 1980). It is presently uncertain as to whether these intrusions postdate or are contemporaneous with the eruption of the Rajmahal tholeiites.

\section{Prince Charles Mountains Lamprophyres}

At the southwest corner of Radok Lake $\left(70^{\circ} 54^{\prime} \mathrm{S}, 67^{\circ} 56^{\prime} \mathrm{E}\right)$ in the Prince Charles Mountains of Antarctica (Fig. 1), two sills occur in conglomerate near the base of an upper Permian sedimentary sequence (Kemp, 1969). They are examples of the fairly rare ultramafic lamprophyre alnoite and have been described by Walker and Mond (1971). The lower sill is about $4 \mathrm{~m}$ thick at its western extremity, thickening eastward to 20 $\mathrm{m}$. The upper sill, which is stratigraphically about $300 \mathrm{~m}$ above the lower, is about $5 \mathrm{~m}$ thick. The sills are exposed in vertical cliffs and can be traced horizontally over a distance of $1 \mathrm{~km}$. Thin dykes also occur in the sediments $6.5-11 \mathrm{~km}$ northeast of the sills. K-Ar dating on phlogopite separates from the sills gave ages between 108 and $110 \mathrm{Ma}$ (Walker and Mond, 1971).

\section{MAJOR AND TRACE ELEMENT GEOCHEMISTRY}

\section{Methods}

Samples were cleaned before being crushed in an agate shatterbox. Trace element analysis was conducted on 46-mmdiameter powder briquettes, made from $15 \mathrm{~g}$ of rock powder by adding 20 drops of a $7 \%$ solution of polyvinyl alcohol and subjecting the mixture to a pressure of 15 tons in a steel die. For major element analysis, the rock powders were dried overnight at $120^{\circ} \mathrm{C}$ before igniting them at $800^{\circ} \mathrm{C}$. This was followed by accurately weighing $1 \mathrm{~g}$ of ignited rock powder with $5 \mathrm{~g}$ of Johnson Matthey spectroflux 100B into a platinum crucible and fusing the mixture at $1200^{\circ} \mathrm{C}$. The melt was pressed into a glass disk on an aluminum mold.

$\mathrm{X}$-ray fluorescence (XRF) analysis was conducted at the University of Leicester using a Philips PW1400 automatic spectrometer. Major elements and $\mathrm{Nb}, \mathrm{Zr}, \mathrm{Y}, \mathrm{Sr}, \mathrm{Rb}, \mathrm{Th}$, and $\mathrm{Ni}$ were determined using a $\mathrm{Rh} \mathrm{X}$-ray tube. The trace elements $\mathrm{V}, \mathrm{Cr}, \mathrm{Ba}, \mathrm{La}, \mathrm{Ce}$, and $\mathrm{Nd}$ were determined using a W X-ray tube. Details of operating conditions and data quality are given by Marsh et al. (1980) and Weaver et al. (1983).

Instrumental neutron activation analysis (INAA) of the rare-earth elements (REE) and Th, Ta, Hf, and Sc was conducted on selected samples at the University of Durham using a method similar to that detailed by Leat et al. (1990), counting samples for $24 \mathrm{hr}$.

The XRF analyses of standard W1 and the INAA analyses of standards BR and BOB-1, performed in conjunction with this work, are given in Saunders et al. (in press).

\section{Kerguelen Plateau}

Legs 119 and 120 recovered Kerguelen Plateau basement at Sites 738, 747, 749, and 750 (Fig. 2), which consisted of moderately fresh to highly altered basalt. The secondary mineral assemblage consisted of smectites, zeolites, and calcite. The basalts range from aphyric to highly porphyritic, containing phenocrysts of plagioclase, clinopyroxene and olivine. The lava flow drilled at Site 748 is a highly altered analcite-bearing alkali basalt containing plagioclase and clinopyroxene phenocrysts. The MD48 basement dredge samples recovered from the $77^{\circ} \mathrm{E}$ Graben and the northwest flanks of the Kerguelen Plateau consisted of moderately to highly altered basalt (Bassias et al., 1987; Leclaire et al., 1987; Davies et al., 1989).

New major and trace element analyses for Leg 120 and MD48 Kerguelen Plateau basalts are given in Table 1. Most are olivine normative tholeiites, with $\mathrm{MgO}, \mathrm{Ni}$, and $\mathrm{Cr}$ contents for the Leg 120 samples ranging from $5.8 \%$ to $10.2 \%, 29$ to $156 \mathrm{ppm}$, and 83 to $401 \mathrm{ppm}$, respectively. The MD48 dredge samples contain more evolved compositions, with $\mathrm{MgO}$ varying between $3.9 \%$ to $5.7 \%$. The tholeiites have been variably affected by hydrothermal alteration, as indicated by their large range in volatile contents (e.g., LOI $=0.1 \%$ to $7.3 \%$ ) and the generally nonsystematic behavior of the more mobile elements (e.g., $\mathrm{Rb}, \mathrm{K}$, and $\mathrm{Na}$ ) with magmatic fractionation indexes such as $\mathrm{MgO}$ or $\mathrm{Zr}$ (Schlich, Wise, et al., 1989).

In terms of immobile incompatible element abundances and ratios, Leg 120 basalts exhibit significant inter- and intrasite variations. For example, Site 747 basalts have lower $\mathrm{Ti} / \mathrm{Zr}$ ratios ( 74 to 83$)$ than those of Site 749 (94 to 139) and Site 750 (150 to 185), suggesting that the first are derived from a more enriched source (Fig. 5). The Site 749 tholeiites appear to consist of two distinct magma types: most of the data have $\mathrm{Ti} / \mathrm{Zr}$ ratios clustering around 100 , but a second, more depleted, group has $\mathrm{Ti} / \mathrm{Zr}$ ratios ranging from 122 to 139 . The MD48 tholeiites range in $\mathrm{Ti} / \mathrm{Zr}$ ratios from 74 to 97.

Figure 6 consists of MORB-normalized multi-element and chondrite-normalized REE plots and illustrates the large range in incompatible element ratios exhibited by Kerguelen Plateau tholeiites. Moderate to strong enrichment of Th and the light REE (LREE) is shown by samples from Site $747\left(\mathrm{La}_{\mathrm{N}} / \mathrm{Yb}_{\mathrm{N}}=\right.$ 3.2 to 4.7$)$, Site $738\left(\mathrm{La}_{N} / \mathrm{Yb}_{\mathrm{N}}=4.2\right)$, and the MD48 basalts dredged from the $77^{\circ} \mathrm{E}$ Graben and the northern part of the Kerguelen Plateau $\left(\mathrm{La}_{\mathrm{N}} / \mathrm{Yb}_{\mathrm{N}}=2.2\right.$ to 6.1). In contrast, basalts from Site 749 are slightly enriched in the LREE $\left(\mathrm{La}_{\mathrm{N}} / \mathrm{Yb}_{\mathrm{N}}=\right.$ 1.53 to 1.80 ), whereas basalts from Site 750 in the Raggatt Basin have the lowest $\mathrm{La}_{\mathrm{N}} / \mathrm{Yb}_{\mathrm{N}}$ ratios $(0.88$ to 1.12$)$, being the most similar to normal MORB. Plagioclase accumulation is the most likely explanation for the $\mathrm{Sr}$ spike in the strongly phyric (30\% plagioclase phenocrysts) Sample 120-749C$16 \mathrm{H}-7,69-76 \mathrm{~cm}$ (Fig. 6). A notable feature of the Kerguelen Plateau tholeiites from Sites 738, 747, 750, and MD48 dredge stations 2,5 , and 6 is their fairly low $\mathrm{Nb}$ and Ta concentrations relative to adjacent, similarly incompatible elements (e.g., Th and $\mathrm{La}$ ) in the multi-element plots (Fig. 6). High $\mathrm{La} / \mathrm{Nb}$ ratios $(>1)$ are more normally associated with subduction-related magmatism (e.g., Saunders et al., 1980; Gill, 1981) and some continental flood basalts (e.g., Mantovani et al., 1985) and lamprophyres (e.g., Paul and Potts, 1981). 


\section{Naturaliste Plateau and Bunbury Basalt}

Analyses of Naturaliste Plateau basalts are given by Coleman et al. (1982), who report major and trace element data on seven dredge samples recovered by the Eltanin. They consist of altered plagioclase- and clinopyroxene-phyric basalts. Analyses of the Bunbury Basalt are given by Burgess (1978), averages of which are given by Coleman et al. (1982). The Bunbury Basalt consists of moderately fresh plagioclase- and pyroxene-phyric flows.

New major and trace element data for five Eltanin dredge basalts from the Naturaliste Plateau and seven samples of the Bunbury Basalt are given in Table 2. The location of the samples are shown in Figure 3. Eltanin Samples EL5512-7 and EL5512-8 were also analyzed by Coleman et al. (1982), and their data are shown in Table 2. The two data sets show good agreement, with the exception of Rb.

In contrast to the Kerguelen Plateau basement, the Naturaliste Plateau basalts are all strongly quartz-normative tholeiites (normative quartz $=12.9$ to 15.9 ). Their large normative quartz content is probably, in part, a consequence of alteration, as is also the presence of normative corundum (Table 2 ). The Bunbury Basalt samples are weakly quartz-normative tholeiites. In terms of their compatible elements, the Naturaliste Plateau samples are moderately evolved with $\mathrm{MgO}, \mathrm{Ni}$, and $\mathrm{Cr}$ ranging from $4 \%$ to $5.1 \%$, from 111 to $139 \mathrm{ppm}$, and from 188 to $555 \mathrm{ppm}$, respectively. The Bunbury Basalt samples have slightly higher $\mathrm{MgO}$ contents (5.5\% to $6.5 \%$ ) but lower $\mathrm{Ni}$ (37 to $58 \mathrm{ppm})$ and $\mathrm{Cr}$ (39 to $146 \mathrm{ppm}$ ) values (Coleman et al., 1982, this volume).

The Naturaliste Plateau basalts show stronger LREE enrichment $\left(\mathrm{La}_{\mathrm{N}} / \mathrm{Yb}_{\mathrm{N}}=3.1\right.$ to 4.7$)$ than do the Bunbury Basalt samples $\left(\mathrm{La}_{\mathrm{N}} / \mathrm{Yb}_{\mathrm{N}}=1.54\right.$ to 2.25$)$ (Fig. 7). Both are enriched in highly incompatible elements (e.g., Th, LREE) relative to normal MORB. A feature of the multi-element plots for both the Naturaliste Plateau and Bunbury Basalt samples are the troughs at $\mathrm{Nb}$ and $\mathrm{Ta}$, with $\mathrm{La} / \mathrm{Nb}$ ratios ranging from 1.4 to 3.3.

\section{Rajmahal Basalts and Indian Lamprophyres}

Previous studies on the volcanic rocks of the Rajmahal Traps and Sylhet Traps (e.g., Mahoney et al., 1983; Baksi et al., 1987) have shown that they consist predominantly of quartz-normative tholeiites and basaltic andesites with a phenocryst assemblage of plagioclase, augite, Fe-Ti oxides, and, more rarely, olivine. Analysis of a few samples from the Bengal Basin has also revealed the presence of alkali basalts and olivine-normative tholeiites (Baksi et al., 1987).

Table 3 presents 25 new analyses of the Rajmahal basalts; their locations are shown in Figure 4. They are all quartznormative tholeiites and exhibit varying contents of $\mathrm{MgO}, \mathrm{Ni}$, and $\mathrm{Cr}$, ranging from $5.3 \%$ to $8 \%$, from 18 to $147 \mathrm{ppm}$, and from 105 to $673 \mathrm{ppm}$, respectively.

With the exception of Sample RB 88/34, the Rajmahal tholeiites define two distinct groups in terms of their incompatible element abundances and ratios (Groups I and II; Figs. $5 \mathrm{C}, 8$, and 9). Group I tholeiites are characterized by higher $\mathrm{Ti} / \mathrm{Zr}$ (94 to 118 ), and lower $\mathrm{Zr} / \mathrm{Y}$ (3.1 to 3.9 ), $\mathrm{K}_{2} \mathrm{O}$ (0.15\% to $0.55 \%)$, and $\mathrm{Rb}(0.3$ to $7.2 \mathrm{ppm})$ than the Group II tholeiites $\left(\mathrm{Ti} / \mathrm{Zr}=61\right.$ to $73 ; \mathrm{Zr} / \mathrm{Y}=4.4$ to $4.8 ; \mathrm{K}_{2} \mathrm{O}=0.56 \%$ to $1.2 \%, \mathrm{Rb}$ $=17$ to $33 \mathrm{ppm})$. The $\mathrm{K} / \mathrm{Rb}$ ratios of Group I tholeiites $(\mathrm{K} / \mathrm{Rb}$ $=242$ to 1038$)$ overlap with Group II tholeiites $(\mathrm{K} / \mathrm{Rb}=248$ to $422)$, but are more variable as they range to higher values. The general enrichment in highly incompatible elements (e.g., Th, LREE) of Group II tholeiites over Group I tholeiites is illustrated in Figure 9. It is also interesting that overall Group I tholeiites have lower $\mathrm{La} / \mathrm{Nb}$ ratios $(\mathrm{La} / \mathrm{Nb}=0.8$ to 1.6) than Group II tholeiites ( $\mathrm{La} / \mathrm{Nb}=1.5$ to 2.4$)$. The $\mathrm{La} / \mathrm{Nb}$ ratios of some Group I tholeiites (e.g., $\mathrm{La} / \mathrm{Nb} \leq 1$ ) are typical of oceanic-island basalts.

The geochemistry of the Lower Cretaceous Indian lamprophyres that intrude into the Gondwana sediments has been described by Paul and Potts (1981) and Middlemost et al. (1988). The Indian lamprophyres are characterized by variable $\mathrm{SiO}_{2}$ ( $39.0 \%$ to $54.6 \%$ ), moderate to very high $\mathrm{K}_{2} \mathrm{O}$ ( $2.2 \%$ to $5.9 \%$ ), $\mathrm{MgO}$ (4.7\% to $16.8 \%$ ), $\mathrm{Ni}$ (30 to $930 \mathrm{ppm}$ ), and $\mathrm{Cr}$ (31 to $977 \mathrm{ppm}$ ) and low to high $\mathrm{Al}_{2} \mathrm{O}_{3}$ contents $(4.3 \%$ to $15.1 \%$ ). The lamprophyres show variable enrichment in LREE $\left(\mathrm{La}_{\mathrm{N}} / \mathrm{Yb}_{\mathrm{N}}=29\right.$ to 110), while exhibiting relative depletion in $\mathrm{Ta}$ (and $\mathrm{Nb}$ ) (Fig. 9).

\section{Prince Charles Mountains Lamprophyres}

The petrography of the Radok Lake lamprophyres in the Prince Charles Mountains (Fig. 1) has been described by Walker and Mond (1971). The samples show varying degrees of deuteric alteration, the least altered rocks consisting mostly of phlogopite, melilite, olivine, and nepheline with minor amounts of opaque iron minerals, perovskite, and apatite. Secondary minerals make up $30 \%$ to $70 \%$ of the rock and include serpentine, chlorite, talc, prehnite, calcite, dolomite, and possibly antigorite (Walker and Mond, 1971; N.C.N. Stephenson pers. comm., 1989). Based on their mineralogy and major element chemistry, they classify as alnoites within the ultramafic lamprophyre group (Walker and Mond, 1971).

Two whole-rock samples collected from the lower sill at Radok Lake have been analyzed for major and trace elements (Table 4). They have low $\mathrm{SiO}_{2}(37.2 \%)$, high $\mathrm{MgO}(13.9 \%$ and $16.1 \%)$ and $\mathrm{Ni}(239$ and $281 \mathrm{ppm})$. The alnoites are enriched in LREE, Ta, Nb, Th, K, and Rb. Unlike the ultra-potassic Indian lamprophyres, they have low $\mathrm{La} / \mathrm{Nb}$ ratios $(0.58$ and 0.75 ) and other trace element similarities to ocean island basalts (Fig. 10).

\section{ISOTOPE GEOCHEMISTRY}

\section{Kerguelen Plateau}

Preliminary $\mathrm{Sr}, \mathrm{Nd}$, and $\mathrm{Pb}$ isotopic data for Kerguelen Plateau and Rajmahal basalts are shown in Figures 11-13; the complete data set will be given elsewhere. Samples from the Kerguelen Plateau show a remarkably large variation in isotopic composition; for example, $\varepsilon_{\mathrm{Nd}}$ ranges from 5.2 to -8.5. In terms of individual locations, Site 747 basalts have high $87 \mathrm{Sr} /{ }^{86} \mathrm{Sr}$ ratios $(0.7056$ to 0.7058$)$, whereas $\varepsilon_{\mathrm{Ne}}$ ranges from 2.7 to -4 , overlapping with the most enriched basalts from Kerguelen Island (Fig. 11). In comparison, $\varepsilon_{\mathrm{Nd}}$ is higher and more variable for basalts from Sites $749\left(\varepsilon_{\mathrm{Nd}}=1.9\right.$ to 4.5$)$ and $750\left(\varepsilon_{\mathrm{Nd}}=1.4\right.$ to 5.2$)$. Site 750 tholeiites differ from those of Site 749 in having higher ${ }^{87} \mathrm{Sr} /{ }^{86} \mathrm{Sr}$ ratios. Acid-leaching experiments (Fig. 11) and the high Sr contents of Site 750 tholeiites (Fig. 6) suggest that this is only partly caused by alteration. In marked contrast to the tholeiites from the central and northern part of the Kerguelen Plateau, which have Sr and $\mathrm{Nd}$ isotopic compositions within the mantle array, isotopic analysis of a tholeiite from Site 738 (Alibert, 1991), at the southern tip of the Kerguelen Plateau, gave extreme ${ }^{87} \mathrm{Sr} /{ }^{86} \mathrm{Sr}$ and $\varepsilon_{\mathrm{Nd}}$ values of 0.7090 and 8.5 , respectively (Fig. 13), well outside the range of oceanic (hotspot-related) basalts.

Although the $\mathrm{Pb}$ isotopic compositions of basalts from Sites 748 and 749 overlap with data for Kerguelen Island, the tholeiites from Sites 738, 747, and 750, in comparison, are characterized by lower ${ }^{206} \mathrm{~Pb} / 204 \mathrm{~Pb}$ (17.47 to 17.74), despite major differences in their $\mathrm{Nd}$ and $\mathrm{Sr}$ isotopic compositions. The single analysis of the Site 738 tholeiite (Alibert, 1991) has a very high ${ }^{207} \mathrm{~Pb} / 204 \mathrm{~Pb}$ ratio (15.71), similar to values observed in continental lamproites from western Australia and leucitites from Gaussberg volcano, Antarctica (Fig. 12). 


\begin{tabular}{|c|c|c|c|c|c|c|c|c|c|c|c|c|c|c|c|c|c|c|}
\hline $\begin{array}{c}\text { Hole } \\
\text { Core, section } \\
\text { Interval }(\mathrm{cm})\end{array}$ & $\begin{array}{c}747 \mathrm{C} \\
11 \mathrm{R}-1 \\
6-8\end{array}$ & $\begin{array}{c}747 \mathrm{C} \\
12 \mathrm{R}-2 \\
119-121\end{array}$ & $\begin{array}{c}747 C \\
12 R-4 \\
36\end{array}$ & $\begin{array}{c}747 \mathrm{C} \\
13 \mathrm{R}-3 \\
144-148\end{array}$ & $\begin{array}{l}747 \mathrm{C} \\
14 \mathrm{R}-1 \\
30-34\end{array}$ & $\begin{array}{l}747 \mathrm{C} \\
14 \mathrm{R}-2 \\
16-21\end{array}$ & $\begin{array}{l}747 \mathrm{C} \\
15 \mathrm{R}-1 \\
26-32\end{array}$ & $\begin{array}{l}747 \mathrm{C} \\
16 \mathrm{R}-2 \\
78-80\end{array}$ & $\begin{array}{c}747 C \\
16 R-4 \\
50-53\end{array}$ & $\begin{array}{c}747 \mathrm{C} \\
16 \mathrm{R}-5 \\
103-106\end{array}$ & $\begin{array}{c}748 \mathrm{C} \\
79 \mathrm{R}-5 \\
137-139\end{array}$ & $\begin{array}{c}748 \mathrm{C} \\
79 \mathrm{R}-6 \\
90-94\end{array}$ & $\begin{array}{c}748 \mathrm{C} \\
82 \mathrm{R}-\mathrm{CC} \\
0-2\end{array}$ & $\begin{array}{l}749 \mathrm{C} \\
12 \mathrm{R}-2 \\
64-69\end{array}$ & $\begin{array}{l}749 \mathrm{C} \\
12 \mathrm{R}-3 \\
82-84\end{array}$ & $\begin{array}{c}749 \mathrm{C} \\
12 \mathrm{R}-3 \\
117-120\end{array}$ & $\begin{array}{c}749 \mathrm{C} \\
12 \mathrm{R}-4 \\
138-140\end{array}$ & $\begin{array}{c}749 \mathrm{C} \\
15 \mathrm{R} \cdot 2 \\
118-123\end{array}$ \\
\hline \multicolumn{19}{|c|}{ Major elements: } \\
\hline $\mathrm{SiO}_{2}$ & 51.86 & 50.54 & 50.61 & 50.54 & 49.72 & 50.77 & 49.68 & 50.35 & 49.54 & 50.90 & 50.40 & 49.24 & 51.23 & 54.92 & 52.82 & 52.60 & 52.33 & 53.75 \\
\hline $\mathrm{TiO}_{2}$ & 2.03 & 1.55 & 1.63 & 1.65 & 1.68 & 1.97 & 1.26 & 1.24 & 1.29 & 1.21 & 2.81 & 2.74 & 2.72 & 1.11 & 1.54 & 1.40 & 1.40 & 1.44 \\
\hline $\mathrm{Al}_{2} \mathrm{O}_{3}$ & 17.42 & 15.64 & 15.05 & 16.57 & 16.53 & 16.87 & 16.76 & 16.52 & 16.33 & 17.23 & 18.06 & 17.50 & 17.83 & 12.99 & 15.58 & 14.01 & 14.17 & 14.48 \\
\hline $\mathrm{Fe}_{2} \mathrm{O}_{3}$ & 10.17 & 11.38 & 12.01 & 10.87 & 11.42 & 12.17 & 10.88 & 10.76 & 10.27 & 10.62 & 8.69 & 8.77 & 7.61 & 11.00 & 11.47 & 13.26 & 12.50 & 11.55 \\
\hline $\mathrm{MnO}$ & 0.17 & 0.17 & 0.20 & 0.15 & 0.15 & 0.14 & 0.17 & 0.21 & 0.21 & 0.16 & 0.08 & 0.09 & 0.09 & 0.11 & 0.16 & 0.17 & 0.15 & 0.19 \\
\hline $\mathrm{MgO}$ & 6.22 & 7.53 & 7.65 & 7.85 & 7.97 & 6.94 & 8.50 & 8.38 & 9.11 & 7.47 & 7.01 & 7.54 & 6.98 & 8.18 & 6.80 & 5.82 & 5.85 & 6.35 \\
\hline $\mathrm{CaO}$ & 9.80 & 11.04 & 11.57 & 10.55 & 10.16 & 7.89 & 9.18 & 9.60 & 10.49 & 9.59 & 6.73 & 6.71 & 6.81 & 6.94 & 8.36 & 9.47 & 9.12 & 9.79 \\
\hline $\mathrm{Na}_{2} \mathrm{O}$ & 2.73 & 2.43 & 2.31 & 2.59 & 2.50 & 2.76 & 2.01 & 1.92 & 2.13 & 1.88 & 4.61 & 4.72 & 4.80 & 3.27 & 3.31 & 2.92 & 2.77 & 2.95 \\
\hline $\mathrm{K}_{2} \mathrm{O}$ & 0.673 & 0.529 & 0.238 & 0.511 & 0.588 & 1.110 & 1.208 & 1.778 & 0.893 & 1.998 & 0.497 & 0.557 & 1.318 & 2.211 & 0.628 & 1.179 & 1.004 & 0.472 \\
\hline $\mathrm{P}_{2} \mathrm{O}_{5}$ & 0.214 & 0.187 & 0.200 & 0.213 & 0.21 & 0.211 & 0.199 & 0.172 & 0.179 & 0.158 & 1.128 & 1.122 & 1.103 & 0.161 & 0.178 & 0.168 & 0.162 & 0.171 \\
\hline Total & 101.29 & 101.00 & 101.47 & 101.49 & 100.93 & 100.83 & 99.85 & 100.93 & 100.44 & 101.22 & 100.02 & 98.99 & 100.49 & 100.89 & 100.85 & 101.00 & 99.46 & 101.14 \\
\hline LOI & 1.88 & 1.26 & 0.67 & 1.46 & 2.05 & 3.00 & 5.20 & 3.66 & 2.73 & 3.63 & 5.66 & 7.14 & 4.86 & 2.60 & 1.14 & 1.72 & 1.13 & 0.13 \\
\hline \multicolumn{19}{|l|}{ CIPW norms: } \\
\hline & 1.83 & & & & & & & & & & & & & & 0.67 & 0.54 & 2.27 & 3.47 \\
\hline Cor & & & & & & & & & & & 0.41 & & & & & & & \\
\hline Or & 3.98 & 3.13 & 1.41 & 3.02 & 3.47 & 6.56 & 7.14 & 10.51 & 5.28 & 11.81 & 2.94 & 3.29 & 7.79 & 13.07 & 3.71 & 6.97 & 5.93 & 2.79 \\
\hline $\mathrm{Ab}$ & 23.10 & 20.56 & 19.55 & 21.92 & 21.16 & 23.36 & 17.01 & 16.25 & 18.02 & 15.91 & 39.01 & 39.94 & 40.62 & 27.67 & 28.01 & 24.71 & 23.44 & 24.96 \\
\hline \multirow{2}{*}{\multicolumn{19}{|c|}{$\mathrm{Ne}$}} \\
\hline & & & & & & & & & & & & & & & & & & \\
\hline Di & 11.38 & 19.09 & 21.37 & 15.37 & 13.77 & 6.07 & 9.03 & 12.46 & 15.01 & 11.33 & & 0.83 & 2.69 & 15.62 & 11.91 & 20.12 & 17.32 & 18.58 \\
\hline $\mathrm{Hy}$ & 20.71 & 19.09 & 22.16 & 18.01 & 17.22 & 25.00 & 22.62 & 17.45 & 15.26 & 19.40 & 12.78 & 4.34 & 2.04 & 21.98 & 24.43 & 20.52 & 20.94 & 20.33 \\
\hline ol & & 2.59 & 0.30 & 4.64 & 6.51 & 2.08 & 5.22 & 7.51 & 8.97 & 4.66 & 8.66 & 15.58 & 14.43 & 2.98 & & & & \\
\hline Mt & 1.76 & 1.96 & 2.07 & 1.88 & 1.97 & 2.10 & 1.88 & 1.86 & 1.77 & 1.83 & 1.50 & 1.51 & 1.31 & 1.90 & 1.98 & 2.29 & 2.16 & 1.99 \\
\hline $\mathrm{Ilm}$ & 3.86 & 2.94 & 3.10 & 3.13 & 3.19 & 3.74 & 2.39 & 2.36 & 2.45 & 2.30 & 5.34 & 5.20 & 5.17 & 2.11 & 2.92 & 2.66 & 2.66 & 2.73 \\
\hline Ap & 0.50 & 0.43 & 0.46 & 0.49 & 0.49 & 0.49 & 0.46 & 0.40 & 0.41 & 0.37 & 2.61 & 2.60 & 2.56 & 0.37 & 0.41 & 0.39 & 0.38 & 0.40 \\
\hline \multicolumn{19}{|l|}{ XRF: } \\
\hline $\mathrm{Nb}$ & 11.8 & 7.4 & 9.3 & 10.2 & 9.2 & 10.5 & 7.9 & 8.1 & 7.7 & 7.0 & 123.4 & 121.9 & 125.5 & 4.3 & 5.7 & 4.7 & 5.2 & 5.8 \\
\hline $\mathrm{Zr}$ & 159.0 & 112.7 & 122.6 & 132.4 & 135.2 & 152.8 & 101.1 & 98.1 & 100.4 & 96.7 & 605.0 & 599.3 & 621.6 & 54.5 & 93.6 & 84.0 & 87.9 & 91.2 \\
\hline Y & 28.1 & 23.0 & 26.9 & 24.2 & 27.5 & 37.0 & 23.3 & 22.8 & 18.9 & 23.2 & 26.4 & 27.7 & 30.0 & 22.5 & 30.1 & 31.2 & 30.2 & 31.3 \\
\hline Sr & 265.3 & 232.1 & 243.9 & 259.2 & 248.8 & 227.9 & 233.3 & 250.4 & 240.4 & 233.5 & 1226.9 & 1130.8 & 1125.2 & 137.6 & 217.5 & 202.4 & 212.8 & 228.3 \\
\hline $\mathrm{Rb}$ & 8.4 & 11.2 & 2.4 & 9.2 & 6.7 & 18.9 & 17.5 & 8.1 & 20.3 & 18.5 & 7.3 & 7.8 & 7.8 & 18.2 & 12.8 & 41.1 & 28.5 & 9.9 \\
\hline Ga & 22.9 & 20.0 & 19.1 & 21.3 & 19.7 & 22.7 & 17.2 & 18.4 & 18.4 & 22.0 & 18.2 & 18.7 & 19.4 & 16.1 & 22.7 & 20.9 & 22.2 & 23.9 \\
\hline $\mathrm{Zn}$ & 130.4 & 92.1 & 93.4 & 97.9 & 93.2 & 98.6 & 79.2 & 77.9 & 71.1 & 65.9 & 76.6 & 79.0 & 86.5 & 73.2 & 121.1 & 103.4 & 97.7 & 97.4 \\
\hline $\mathrm{Ni}$ & 55.6 & 69.1 & 65.5 & 75.0 & 73.8 & 50.9 & 107.9 & 100.8 & 107.0 & 71.6 & 224.3 & 181.7 & 210.7 & 52.2 & 29.7 & 30.6 & 30.0 & 31.2 \\
\hline V & 377.3 & 306.1 & 299.3 & 250.0 & 265.4 & 326.2 & 194.6 & 187.7 & 211.3 & 201.0 & 179.0 & 169.5 & 168.1 & 199.3 & 278.8 & 234.0 & 247.3 & 243.5 \\
\hline $\mathrm{Cr}$ & 182.2 & 278.6 & 224.0 & 82.6 & 90.5 & 114.2 & 351.2 & 371.1 & 359.6 & 401.4 & 274.2 & 166.0 & 218.1 & 235.0 & 274.3 & 237.8 & 235.4 & 229.2 \\
\hline $\mathrm{Ba}$ & 142.9 & 160.7 & 147.7 & 250.3 & 246.7 & 228.8 & 187.5 & 205.5 & 175.9 & 229.3 & 1351.0 & 1661.0 & 1449.0 & 171.7 & 120.8 & 98.8 & 104.7 & 107.4 \\
\hline $\mathrm{La}$ & 14.0 & 11.7 & 10.7 & 15.5 & 14.8 & 21.2 & 13.0 & 14.6 & 12.4 & 13.4 & 109.5 & 108.9 & 109.3 & 4.5 & 6.1 & 8.2 & 5.8 & 6.2 \\
\hline $\mathrm{Ce}$ & 36.0 & 24.5 & 30.3 & 32.9 & 37.8 & 48.2 & 33.3 & 30.3 & 30.5 & 31.3 & 214.9 & 218.3 & 220.3 & 10.9 & 16.4 & 14.6 & 14.8 & 19.3 \\
\hline $\mathrm{Nd}$ & 19.1 & 14.3 & 15.1 & 17.5 & 18.5 & 24.3 & 17.0 & 15.6 & 15.1 & 16.4 & 89.0 & 88.0 & 89.4 & 6.2 & 11.5 & 9.2 & 10.9 & 9.7 \\
\hline \multicolumn{19}{|l|}{ INAA: } \\
\hline $\mathrm{La}$ & 13.2 & & 12.5 & & & & & & 13.3 & 12.3 & & 105.0 & 106.0 & & & & & \\
\hline $\mathrm{Ce}$ & 32.0 & & 28.6 & & & & & & 28.6 & 25.5 & & 224.0 & 230.0 & & & & & \\
\hline Nd & 18.3 & & 17.7 & & & & & & 17.7 & 13.5 & & 103.0 & 104.0 & & & & & \\
\hline $\mathrm{Sm}$ & 4.7 & & 4.22 & & & & & & 3.59 & 3.50 & & 14.20 & 12.80 & & & & & \\
\hline Eu & 1.38 & & 1.29 & & & & & & 1.07 & 1.03 & & 3.31 & 3.58 & & & & & \\
\hline $\mathrm{Tb}$ & 0.67 & & 0.78 & & & & & & 0.63 & 0.65 & & 1.25 & 1.38 & & & & & \\
\hline $\mathrm{Yb}$ & 2.35 & & 2.76 & & & & & & 2.17 & 1.89 & & 1.8 & 2.21 & & & & & \\
\hline $\mathrm{Lu}$ & 0.30 & & 0.37 & & & & & & 0.31 & 0.28 & & 0.26 & 0.26 & & & & & \\
\hline $\mathrm{Ta}$ & 0.66 & & 0.54 & & & & & & 0.56 & 0.46 & & 9.08 & 7.50 & & & & & \\
\hline $\mathrm{Hf}$ & 3.84 & & 3.05 & & & & & & 2.51 & 2.34 & & 12.40 & 10.80 & & & & & \\
\hline Th & 1.29 & & 1.09 & & & & & & 1.08 & 0.80 & & 11.50 & 10.50 & & & & & \\
\hline w & 6.1 & & 7.6 & & & & & & 6.0 & 5.3 & & 16.4 & 15.7 & & & & & \\
\hline $\mathrm{Sc}$ & 48.0 & & 43.5 & & & & & & 36.7 & 33.8 & & 18.7 & 19.4 & & & & & \\
\hline
\end{tabular}


Table 1 (continued).

\begin{tabular}{|c|c|c|c|c|c|c|c|c|c|c|c|c|c|c|c|c|c|}
\hline $\begin{array}{l}\text { Hole } \\
\text { Core, section } \\
\text { Interval }(\mathrm{cm})\end{array}$ & $\begin{array}{c}749 \mathrm{C} \\
15 \mathrm{R}-5 \\
125-127\end{array}$ & $\begin{array}{c}749 \mathrm{C} \\
15 \mathrm{R}-6 \\
97-100\end{array}$ & $\begin{array}{c}749 \mathrm{C} \\
16 \mathrm{R}-7 \\
69-76\end{array}$ & $\begin{array}{c}750 \mathrm{~B} \\
16 \mathrm{R}-4 \\
47-51\end{array}$ & $\begin{array}{l}750 \mathrm{~B} \\
14 \mathrm{R}-1 \\
47-50\end{array}$ & $\begin{array}{c}750 \mathrm{~B} \\
15 \mathrm{R}-2 \\
88-92\end{array}$ & $\begin{array}{c}750 \mathrm{~B} \\
16 \mathrm{R}-6 \\
54-58\end{array}$ & $\begin{array}{c}750 \mathrm{~B} \\
17 \mathrm{R}-1 \\
5-7\end{array}$ & $\begin{array}{c}750 \mathrm{~B} \\
17 \mathrm{R}-3 \\
23-26\end{array}$ & $\begin{array}{c}750 \mathrm{~B} \\
17 \mathrm{R}-3 \\
50-54\end{array}$ & $\begin{array}{r}\text { MD48-86 } \\
\text { DR 02-2 }\end{array}$ & $\begin{array}{l}\text { MD48-86 } \\
\text { DR 05-1 }\end{array}$ & $\begin{array}{l}\text { MD48-86 } \\
\text { DR } 05-2\end{array}$ & $\begin{array}{l}\text { MD48-86 } \\
\text { DR 05-3 }\end{array}$ & $\begin{array}{l}\text { MD48-86 } \\
\text { DR } 06\end{array}$ & $\begin{array}{c}\text { MD48-86 } \\
\text { DR } 07\end{array}$ & $\begin{array}{l}\text { MD48-86 } \\
\text { DR } 08-4\end{array}$ \\
\hline \multicolumn{18}{|c|}{ Major elements: } \\
\hline $\mathrm{SiO}_{2}$ & 52.73 & 50.55 & 49.98 & 51.04 & 42.65 & 50.38 & 50.33 & 50.40 & 49.21 & 49.75 & 50.74 & 50.02 & 50.67 & 50.61 & 49.05 & 50.08 & 49.74 \\
\hline $\mathrm{TiO}_{2}$ & 1.52 & 1.75 & 0.92 & 0.73 & 0.93 & 0.71 & 0.76 & 0.75 & 1.17 & 1.23 & 2.47 & 1.72 & 1.66 & 1.61 & 2.38 & 1.70 & 2.26 \\
\hline $\mathrm{Al}_{2} \mathrm{O}_{3}$ & 15.18 & 14.90 & 19.01 & 15.44 & 17.75 & 15.42 & 16.01 & 15.71 & 15.77 & 16.55 & 17.92 & 16.66 & 15.84 & 16.00 & 17.07 & 16.39 & 15.13 \\
\hline $\mathrm{Fe}_{2} \mathrm{O}_{3}$ & 11.95 & 13.41 & 9.15 & 11.96 & 26.12 & 11.95 & 11.17 & 11.68 & 14.62 & 13.96 & 9.71 & 11.79 & 11.75 & 10.26 & 14.14 & 12.44 & 13.85 \\
\hline $\mathrm{MnO}^{\circ}$ & 0.17 & 0.19 & 0.13 & 0.19 & 0.06 & 0.19 & 0.18 & 0.18 & 0.18 & 0.13 & 0.17 & 0.19 & 0.19 & 0.14 & 0.20 & 0.23 & 0.21 \\
\hline $\mathrm{MgO}$ & 7.22 & 6.82 & 7.01 & 9.33 & 6.43 & 10.15 & 8.47 & 8.99 & 8.36 & 9.87 & 5.72 & 4.99 & 6.18 & 5.80 & 3.88 & 5.94 & 4.91 \\
\hline $\mathrm{CaO}$ & 8.31 & 9.96 & 12.11 & 11.00 & 0.34 & 9.97 & 11.36 & 11.31 & 9.01 & 6.55 & 6.65 & 9.41 & 9.82 & 9.58 & 8.76 & 9.57 & 9.56 \\
\hline $\mathrm{Na}_{2} \mathrm{O}$ & 3.42 & 3.21 & 2.48 & 1.97 & 0.45 & 1.81 & 2.05 & 1.99 & 1.99 & 2.09 & 3.62 & 3.32 & 3.44 & 3.26 & 3.67 & 3.49 & 3.07 \\
\hline $\mathrm{K}_{2} \mathrm{O}$ & 0.543 & 0.228 & 0.081 & 0.092 & 5.283 & 0.109 & 0.095 & 0.053 & 0.189 & 0.259 & 2.332 & 1.083 & 0.569 & 1.020 & 0.895 & 0.632 & 1.440 \\
\hline $\mathrm{P}_{2} \mathrm{O}_{5}$ & 0.177 & 0.189 & 0.086 & 0.065 & 0.087 & 0.055 & 0.061 & 0.069 & 0.113 & 0.108 & 0.447 & 0.332 & 0.211 & 0.228 & 0.531 & 0.208 & 0.292 \\
\hline Total & 101.22 & 101.21 & 100.96 & 101.82 & 100.10 & 100.74 & 100.49 & 101.13 & 100.61 & 100.50 & 99.78 & 99.51 & 100.33 & 98.51 & 100.58 & 100.68 & 100.46 \\
\hline LOI & 1.35 & 0.94 & 0.90 & 0.98 & 7.30 & 2.34 & 1.18 & 1.26 & 4.31 & 4.22 & 1.97 & 1.44 & 0.90 & 0.97 & 1.84 & 1.16 & 0.83 \\
\hline \multirow{2}{*}{\multicolumn{18}{|c|}{$\begin{array}{l}\text { CIPW norms: } \\
\text { Qtz } \\
\text { Cor }\end{array}$}} \\
\hline & & & & & & & & & & 0.33 & & & & & & & \\
\hline & & & & & 10.88 & & & & & 1.18 & & & & & & & \\
\hline Or & 3.21 & 1.35 & 0.48 & 0.54 & 31.22 & 0.64 & 0.56 & 0.31 & 1.12 & 1.53 & 13.78 & 6.40 & 3.36 & 6.03 & 5.29 & 3.73 & 8.51 \\
\hline $\mathrm{Ab}$ & 28.94 & 27.16 & 20.99 & 16.67 & 3.81 & 15.32 & 17.35 & 16.84 & 16.84 & 17.69 & 30.63 & 28.09 & 29.11 & 27.59 & 31.06 & 29.53 & 25.98 \\
\hline An & 24.47 & 25.58 & 40.51 & 33.02 & 1.12 & 33.64 & 34.21 & 33.79 & 33.55 & 31.79 & 25.77 & 27.37 & 26.11 & 26.02 & 27.47 & 27.20 & 23.26 \\
\hline \multicolumn{18}{|l|}{$\mathrm{Ne}$} \\
\hline $\begin{array}{l}\mathrm{Di} \\
\mathrm{Hy}\end{array}$ & $\begin{array}{l}12.80 \\
24.47\end{array}$ & $\begin{array}{l}18.65 \\
15.02\end{array}$ & $\begin{array}{l}15.50 \\
14.09\end{array}$ & $\begin{array}{l}1.25 \\
28.30\end{array}$ & 27.05 & 32.41 & 24.63 & $\begin{array}{l}17.86 \\
25.25\end{array}$ & $\begin{array}{r}8.58 \\
32.56\end{array}$ & 4176 & $\begin{array}{l}3.51 \\
6.73\end{array}$ & $\begin{array}{r}14.23 \\
9.11\end{array}$ & $\begin{array}{r}17.49 \\
9.89\end{array}$ & 16.44 & $\begin{array}{r}10.53 \\
744\end{array}$ & $\begin{array}{l}15.64 \\
660\end{array}$ & $\begin{array}{r}18.57 \\
7.43\end{array}$ \\
\hline $\begin{array}{l}\text { Hy } \\
\text { Ol }\end{array}$ & 0.93 & $\begin{array}{r}6.20 \\
6.20\end{array}$ & $\begin{array}{r}5.07 \\
5.07\end{array}$ & 1.40 & 17.26 & 1.57 & $\begin{array}{r}1.49 \\
1.49\end{array}$ & 2.46 & 1.69 & 41.10 & 11.11 & 7.22 & $\begin{array}{l}7.07 \\
7.67\end{array}$ & $\begin{array}{r}4.71 \\
4.72\end{array}$ & $\begin{array}{l}1.44 \\
9.37\end{array}$ & $\begin{array}{r}6.62 \\
11.01\end{array}$ & $\begin{array}{l}7.43 \\
8.15\end{array}$ \\
\hline Mt & 2.06 & 2.31 & 1.58 & 2.06 & 4.51 & 2.06 & 1.93 & 2.02 & 2.52 & 2.41 & 1.68 & 2.04 & 2.03 & 1.77 & 2.44 & 2.15 & 2.39 \\
\hline $\mathrm{Ilm}$ & 2.89 & 3.32 & 1.75 & 1.39 & 1.77 & 1.35 & 1.44 & 1.42 & 2.22 & 2.34 & 4.69 & 3.27 & 3.15 & 3.06 & 4.52 & 3.23 & 4.29 \\
\hline Ap & 0.41 & 0.44 & 0.20 & 0.15 & 0.20 & 0.13 & 0.14 & 0.16 & 0.26 & 0.25 & 1.04 & 0.77 & 0.49 & 0.53 & 1.23 & 0.48 & 0.68 \\
\hline \multicolumn{18}{|l|}{ XRF: } \\
\hline $\mathrm{Nb}$ & 5.8 & 6.3 & 3.9 & & & & & & 4.2 & 3.4 & 12.7 & 5.6 & 5.6 & 6.0 & 11.3 & 7.2 & 12.5 \\
\hline $\mathrm{Zr}$ & 91.1 & 100.0 & 41.2 & 26.9 & 30.0 & 24.2 & 26.7 & 26.3 & 46.9 & 46.5 & 199.8 & 106.7 & 107.1 & 102.0 & 179.4 & 107.3 & 175.0 \\
\hline Y & 29.3 & 32.4 & 17.4 & 19.1 & 13.6 & 18.3 & 19.6 & 20.6 & 24.6 & 21.3 & 36.1 & 30.0 & 33.2 & 34.4 & 47.1 & 28.6 & 42.6 \\
\hline $\mathrm{Sr}$ & 213.5 & 227.7 & 225.0 & 119.6 & 40.8 & 112.9 & 128.4 & 122.5 & 192.5 & 129.3 & 368.2 & 226.3 & 232.2 & 217.5 & 342.4 & 239.2 & 169.1 \\
\hline $\mathrm{Rb}$ & 12.3 & 6.9 & 4.4 & 5.4 & 22.0 & 4.9 & 4.5 & 2.0 & 9.0 & 6.6 & 69.4 & 25.8 & 9.2 & 39.3 & 14.0 & 11.3 & 28.0 \\
\hline $\mathrm{Ga}$ & 22.7 & 21.2 & 18 & 18.5 & 17.4 & 18.0 & 17.7 & 19.1 & 19.8 & 21.2 & 26.8 & 24.6 & 20.6 & 22.7 & 28.5 & 23.9 & 24.6 \\
\hline $\mathrm{Zn}$ & 115.1 & 98.9 & 60.6 & 79.0 & 76.3 & 79.9 & 82.7 & 80.8 & 93.4 & 84.0 & 213.3 & 184.8 & 142.3 & 175.9 & 222.5 & 175.4 & 191.6 \\
\hline $\mathrm{Ni}$ & 29.5 & 39.3 & 69.6 & 103.0 & 156.0 & 108.5 & 115.6 & 112.9 & 120.3 & 108.7 & 27.6 & 71.6 & 49.5 & 51.9 & 51.8 & 54.7 & 64.7 \\
\hline $\mathrm{v}$ & 271.3 & 317.0 & 187.8 & 234.7 & 278.4 & 220.5 & 241.4 & 238.9 & 269.4 & 290.3 & 268.6 & 294.3 & 286.6 & 262.5 & 348.5 & 305.7 & 378.5 \\
\hline $\mathrm{Cr}$ & 259.5 & 149.6 & 278.4 & 100.0 & 131.8 & 92.7 & 100.6 & 106.9 & 192.5 & 241.4 & 168.6 & 340.3 & 309.5 & 333.2 & 186.1 & 315.3 & 170.1 \\
\hline $\mathrm{Ba}$ & 113.8 & 93.9 & 49.4 & 47.2 & 192.3 & 39.8 & 47.1 & 34.5 & 30.4 & 20.9 & 140.4 & 98.8 & 57.2 & 94.9 & 137.6 & 67.3 & 180.2 \\
\hline La & 6.5 & 6.5 & 4.1 & 5.2 & 6.1 & 3.5 & 5.4 & 2.6 & 6.2 & 4.1 & 17.9 & 9.7 & 7.2 & 9.1 & 15.4 & 9.1 & 17.4 \\
\hline $\mathrm{Ce}$ & 15.2 & 21.9 & 9.0 & & & & 6.8 & 3.9 & 8.0 & & 47.5 & 20.2 & 20.4 & 17.9 & 34.7 & 19.6 & 42.5 \\
\hline Nd & 10.6 & 13.1 & 5.5 & & & & 2.1 & 3.6 & 7.0 & & 27.5 & 14.8 & 13.5 & 13.6 & 23.5 & 13.7 & 20.0 \\
\hline \multicolumn{18}{|l|}{ INAA: } \\
\hline $\mathrm{La}$ & 6.8 & & 3.2 & & & 2.5 & & & 4.0 & & 17.8 & & 10.4 & & 19.8 & 7.0 & 16.0 \\
\hline $\mathrm{Ce}$ & 16.1 & & 9.6 & & & 5.6 & & & 8.9 & & 47.0 & & 21.0 & & 52.0 & 17.3 & 36.0 \\
\hline Nd & 11.9 & & 6.3 & & & 4.5 & & & 6.3 & & 21.0 & & 13.4 & & 28.0 & 11.6 & 19.6 \\
\hline Sm & 3.64 & & 2.06 & & & 1.41 & & & 2.32 & & 5.30 & & 4.70 & & 7.40 & 3.77 & 5.60 \\
\hline Eu & 1.24 & & 0.83 & & & 0.59 & & & 0.84 & & 1.74 & & 1.57 & & 2.19 & 1.29 & 1.49 \\
\hline $\mathrm{Tb}$ & 0.69 & & 0.53 & & & 0.43 & & & 0.58 & & 0.80 & & 0.81 & & 1.07 & 0.82 & 1.10 \\
\hline $\mathrm{Yb}$ & 2.71 & & 1.50 & & & 2.04 & & & 2.57 & & 2.11 & & 2.85 & & 4.00 & 2.27 & 3.30 \\
\hline Lu & 0.39 & & 0.22 & & & 0.30 & & & 0.34 & & 0.33 & & 0.47 & & 0.70 & 0.38 & 0.55 \\
\hline $\mathrm{Ta}$ & 0.40 & & 0.15 & & & 0.10 & & & 0.19 & & 0.54 & & 0.40 & & 0.68 & 0.39 & 0.85 \\
\hline Hf & 2.16 & & 1.08 & & & 0.76 & & & 1.16 & & 4.10 & & 2.40 & & 4.20 & 2.41 & 4.09 \\
\hline Th & 0.67 & & 0.24 & & & 0.21 & & & 0.49 & & 2.50 & & 1.50 & & 2.60 & 0.70 & 2.00 \\
\hline W & 6.2 & & 1.9 & & & 3.3 & & & 4.0 & & 1.8 & & 3.9 & & & 3.2 & 2.2 \\
\hline $\mathrm{Sc}$ & 34.5 & & 30.8 & & & 40.9 & & & 38.9 & & 29.9 & & 42.2 & & & 35.6 & 40.7 \\
\hline
\end{tabular}

Note: $\mathrm{LOI}=$ loss on ignition. 


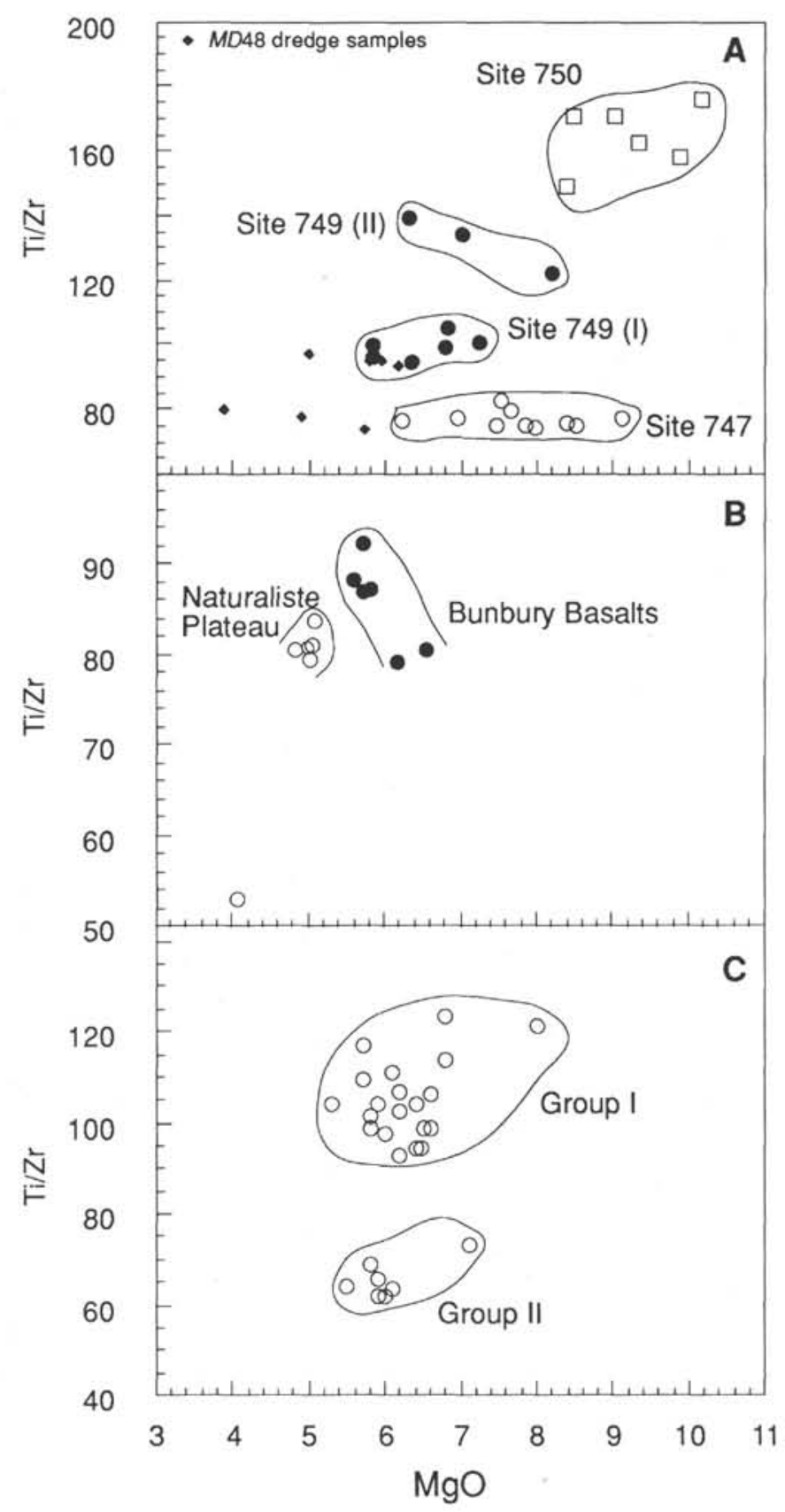

Figure 5. Plots of the $\mathrm{MgO}$ vs. $\mathrm{Ti} / \mathrm{Zr}$ ratio for samples from (A) Kerguelen Plateau, (B) Naturaliste Plateau and Bunbury Basalt, and (C) Rajmahal tholeiites.

On a Pb-Sr diagram (Fig. 13A), all of the Kerguelen Plateau samples lie above the Indian Ocean MORB field, with some falling in the Kerguelen Island field. In the $\mathrm{Pb}-\varepsilon_{\mathrm{Nd}}$ plot, a number of the plateau samples fall between the MORB and Kerguelen Island fields. The low $206 \mathrm{~Pb} / 204 \mathrm{~Pb}$ tholeiites from Sites 738,747 , and 750 plot roughly between the fields of Indian Ocean MORB and Western Australian lamproites (Fig. 13).

\section{Rajmahal Basalts}

The $\mathrm{Sr}$ and Nd isotopic data for the Rajmahal basalts define two distinct groups, with ${ }^{87} \mathrm{Sr} /{ }^{86} \mathrm{Sr}$ and $\varepsilon_{\mathrm{Nd}}$ values ranging from 0.7037 to 0.7053 and 5.1 to 2.9 (Group I) and 0.7064 to 0.7075 and -1.5 to -4.4 (Group II), respectively. This mirrors the variations in incompatible elements (Fig. 8). Most of the Group I tholeiites have $\mathrm{Sr}$ and $\mathrm{Nd}$ isotopic compositions similar to Site 749 basalts from the Kerguelen Plateau, although two Rajmahal samples are distinguished by higher $87 \mathrm{Sr} /{ }^{86} \mathrm{Sr}$ values (Fig. 11). The Rajmahal basalts are characterized by low ${ }^{206} \mathrm{~Pb} /{ }^{204} \mathrm{~Pb}(17.30$ to 17.69$)$ and high ${ }^{207} \mathrm{~Pb} /{ }^{04} \mathrm{~Pb}$ (15.59 to 15.62 ) ratios (Fig. 12).

\section{DISCUSSION}

Kerguelen Plateau basalts have $\mathrm{Sr}$ and Nd isotopic compositions lying outside the field for Indian Ocean MORB, thus excluding the possibility that the plateau represents a piece of old, uplifted normal ocean crust (Fig. 13). With the exception of Site 738, the $\mathrm{Sr}$ and Nd isotopic data are within the range of hotspot-related oceanic basalts, those from Sites 747 and 748 overlapping with the field for the most recent basalts from Kerguelen Island (Fig. 13). However, basalts from Kerguelen Island are characterized by higher ${ }^{206} \mathrm{~Pb} /{ }^{204} \mathrm{~Pb}$ ratios than plateau samples from Sites 738, 747, 750, and MD48 DR2 (Fig. 13). The low ${ }^{206} \mathrm{~Pb} / 204 \mathrm{~Pb}$ values of these particular samples may indicate the involvement of components derived from the continental lithosphere (discussed below). Despite the geochemical complications that have apparently arisen through interactions of the plateau source with continental lithosphere, a number of samples do show evidence for the involvement of Kerguelen Island-type mantle (Fig. 13), supporting the hotspot (Kerguelen-Heard plume [KHP]) hypothesis for most of the plateau, as do the plate reconstructions (Fig. 1, inset; Davies et al., 1989; Storey et al., 1989). One important difference between the younger basalts of Kerguelen and Heard islands, which were erupted in an intraplate environment (e.g., Storey et al., 1988), and the plateau samples is that the latter have lower abundances of such incompatible elements as $\mathrm{Th}, \mathrm{Nb}, \mathrm{Ta}, \mathrm{Zr}$, and LREE, implying much higher degrees of melting of the KHP source during formation of the Kerguelen Plateau. In this respect, the Kerguelen Plateau samples are similar to basalts from other large-volume, hotspot-related oceanic magmatic provinces, such as the Caribbean Plateau, the Ontong Java Plateau, and Nauru Basin (e.g., Floyd, 1989). These observations are consistent with a near- or on-ridge setting for the Kerguelen Plateau (perhaps analogous to Iceland), an environment that would favor extensive melting of an upwelling mantle plume (McKenzie and Bickle, 1988; Storey et al., 1991). It has also been suggested that the largest oceanic plateaus (e.g., Kerguelen Plateau, Ontong Java Plateau) may have formed by melting of the large heads thought to form during the initiation of mantle plumes (Richards et al., 1989).

Low ${ }^{206} \mathrm{~Pb} / 204 \mathrm{~Pb}$ and sometimes high ${ }^{207} \mathrm{~Pb} / 204 \mathrm{~Pb}$ ratios are a feature of old continental mantle lithosphere (e.g., Nelson et al., 1986; Hawkesworth et al., 1990). An extreme expression of this lithospheric signature is shown by western Australian lamproites (Figs. 12 and 13). One explanation for the low ${ }^{206} \mathrm{~Pb} / 204 \mathrm{~Pb}$ values of some Kerguelen Plateau tholeiites is that Gondwana continental mantle lithosphere was incorporated into the Kerguelen plume source during the formation of the plateau. Contamination by lithospheric components was also suggested on the basis of the high $\mathrm{La} / \mathrm{Ta}(\mathrm{Nb})$ and $\mathrm{Th} / \mathrm{Ta}(\mathrm{Nb})$ ratios of some plateau tholeiites (Storey et al., 1989). The occurrence of Indian Ocean MORBs with low ${ }^{206} \mathrm{~Pb} / 204 \mathrm{~Pb}$ ratios has likewise been considered in terms of contamination by lithosphere detachment (e.g., Mahoney et al., 1989, in press). Thermal mobilization of the Gondwana mantle lithosphere by the KHP is plausible given the small size of the Indian Ocean basin $(700 \mathrm{~km})$ at the time of plateau formation and the 1000-2000-km-diameter heads attributed to mantle 


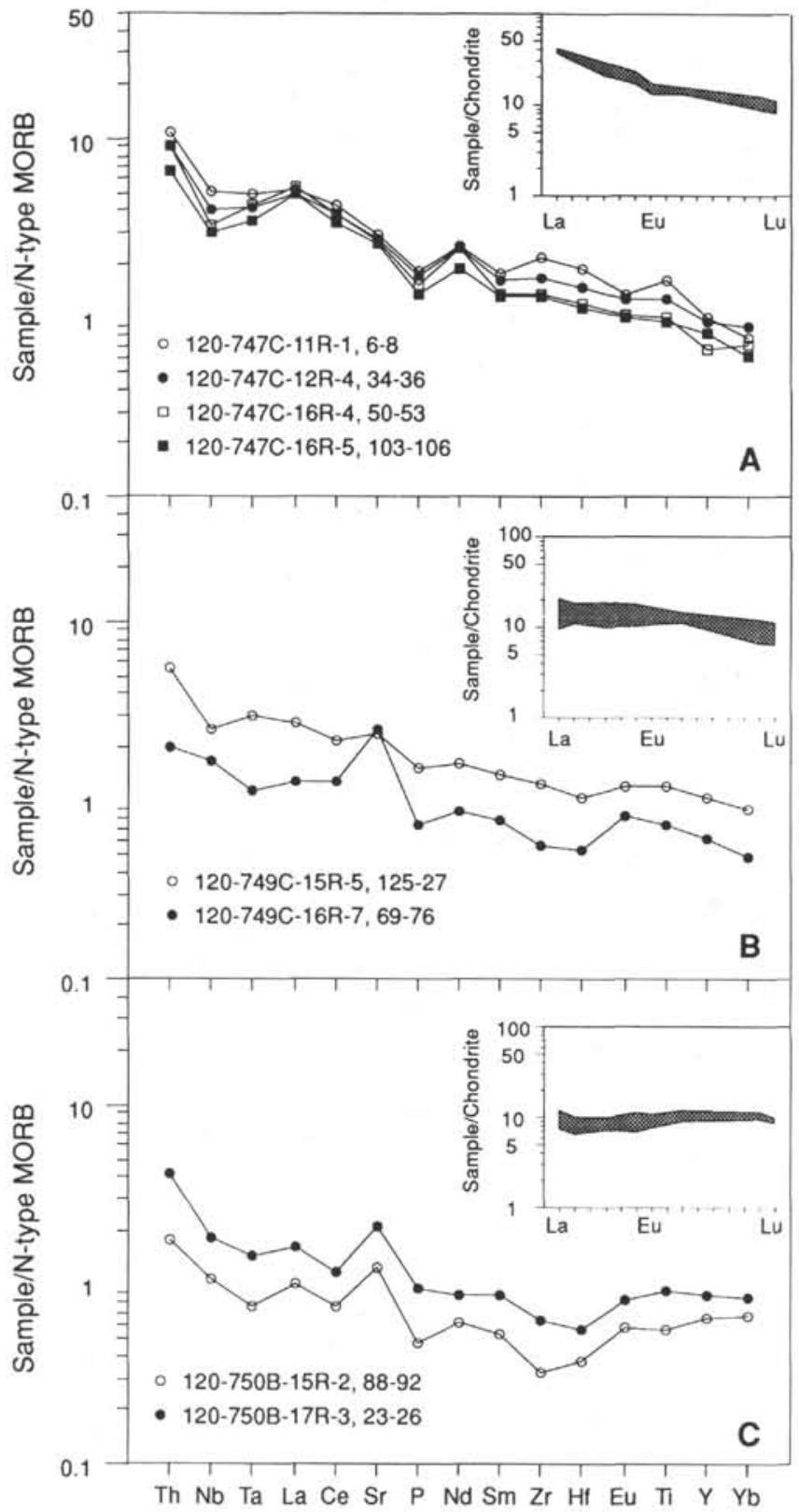

Figure 6. MORB-normalized incompatible element plots and (insets) chondrite normalized REE plots for (A, B, C) Leg 120 basement tholeiites, (D) Leg 119 basement tholeiite, and (E, F) MD48 dredge samples. Leg 119 data from Alibert (1991). Normalizing values are from Sun and McDonough (1989).

plumes (White and McKenzie, 1989). Although plate reconstructions for Gondwana indicate that the Kerguelen Plateau must be essentially oceanic (Fig. 1; de Wit et al., 1988; Powell et al., 1988), it should be noted that the extreme isotopic compositions shown by a Site 738 tholeiite may indicate that the southernmost part of the plateau is underlain by continental crust (Alibert, 1991), possibly in a setting analogous to the North Atlantic Rockall Plateau (Morton and Taylor, 1987; Merriman et al., 1988) and Vøring Plateau sequences (Viereck et al., 1988).

Among the continental volcanism that accompanied the breakup of eastern Gondwana and the formation of the Kerguelen Plateau, the Rajmahal basalts are the most signifi-

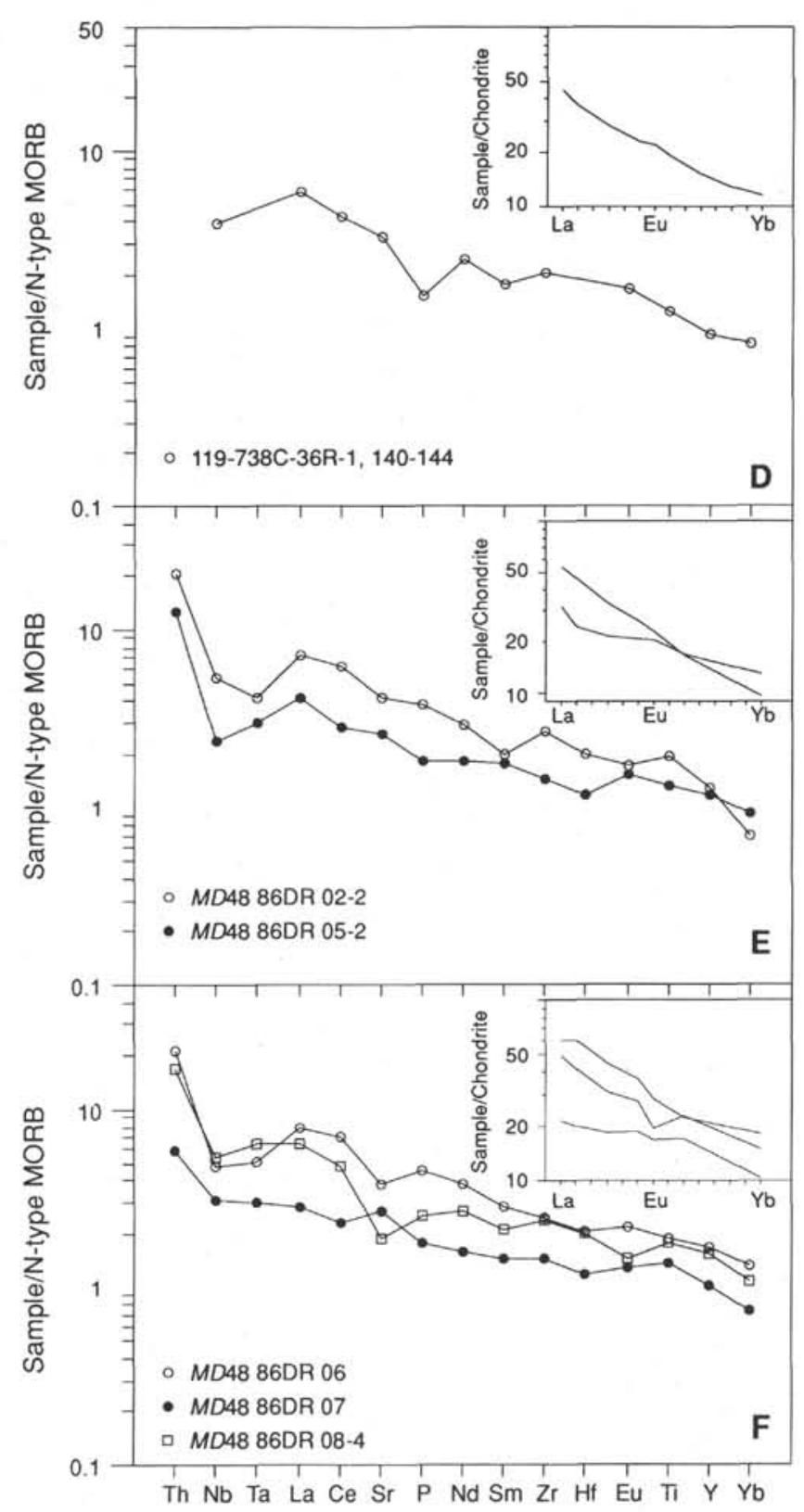

Figure 6 (continued).

cant in terms of volume. The eruption of both may have been partly contemporaneous. Group I Rajmahal tholeiites with low $\mathrm{La} / \mathrm{Nb}$ ratios share strong compositional similarities with some Kerguelen Plateau basalts (Fig. 14), suggesting a direct contribution to Rajmahal volcanism by the KHP, in contrast to the conclusion reached by Mahoney et al. (1983). The $\mathrm{Sr}$ and Nd isotopic compositions of the Group I tholeiites supports this contention, although, their high ${ }^{207} \mathrm{~Pb} /{ }^{204} \mathrm{~Pb}$ ratios also indicate the presence of continental lithosphere components; the preferential enrichment of $\mathrm{Pb}$, relative to $\mathrm{Sr}$ and $\mathrm{Nd}$, in continental lithosphere makes $\mathrm{Pb}$ a sensitive indicator of such contamination. The range in $\mathrm{La} / \mathrm{Nb}$ and $\mathrm{K} / \mathrm{Rb}$ ratios of Group I tholeiites (Fig. 8) also suggests some contamination by continental lithosphere or melts derived therefrom. A probable example of the latter are the Lower Cretaceous Indian lamprophyres, which are characterized by very high $\mathrm{La} / \mathrm{Nb}$ ratios and moderate to high $\mathrm{K} / \mathrm{Rb}$ ratios (up to 1000 ; 
Table 2. Major and trace element analyses of samples from the Naturaliste Plateau and the Bunbury Basalt, Australia.

\begin{tabular}{|c|c|c|c|c|c|c|c|c|c|c|c|c|c|c|}
\hline Sample & EL55 12 & EL5512-2 & EL5512-7 & EL5512-8 & EL5512-9 & EL5512-7* & EL5512-8* & BB1 & BB2 & BB3 & BB4 & BB5 & BB6 & BB7 \\
\hline \multicolumn{15}{|c|}{ Major elements: } \\
\hline $\mathrm{SiO}_{2}$ & 56.38 & 59.94 & 56.63 & 54.65 & 55.63 & 55.03 & 54.82 & 51.91 & 52.16 & 53.25 & 51.69 & 52.66 & 52.98 & 53.11 \\
\hline $\mathrm{TiO}_{2}$ & 1.81 & 1.80 & 1.80 & 1.88 & 1.85 & 1.69 & 1.74 & 1.67 & 2.05 & 2.05 & 1.77 & 1.96 & 1.31 & 1.31 \\
\hline $\mathrm{Al}_{2} \overline{\mathrm{O}}_{3}$ & 17.13 & 15.04 & 16.90 & 18.02 & 17.59 & 16.82 & 17.47 & 16.20 & 14.55 & 14.43 & 15.57 & 15.21 & 14.72 & 14.71 \\
\hline $\mathrm{Fe}_{2} \mathrm{O}_{3}$ & 11.91 & 9.86 & 12.06 & 13.18 & 12.16 & 13.62 & 13.02 & 11.38 & 12.46 & 12.26 & 11.67 & 12.13 & 11.87 & 11.80 \\
\hline $\mathrm{MnO}^{\circ}$ & 0.20 & 0.12 & 0.18 & 0.20 & 0.19 & 0.16 & 0.17 & 0.17 & 0.19 & 0.20 & 0.18 & 0.19 & 0.20 & 0.20 \\
\hline $\mathrm{MgO}$ & 5.04 & 4.04 & 4.99 & 4.98 & 5.00 & 5.08 & 4.80 & 5.80 & 5.71 & 5.81 & 5.71 & 5.57 & 6.16 & 6.54 \\
\hline $\mathrm{CaO}$ & 3.62 & 4.02 & 3.52 & 3.87 & 3.76 & 3.37 & 3.97 & 10.31 & 9.67 & 9.64 & 10.12 & 9.77 & 10.46 & 10.51 \\
\hline $\mathrm{Na}_{2} \mathrm{O}$ & 2.71 & 3.25 & 2.67 & 2.75 & 2.73 & 2.88 & 2.90 & 3.28 & 3.12 & 3.07 & 3.09 & 3.22 & 2.94 & 2.83 \\
\hline $\mathrm{K}_{2} \mathrm{O}$ & 1.01 & 2.31 & 1.14 & 1.01 & 1.02 & 1.11 & 0.88 & 0.23 & 0.38 & 0.48 & 0.33 & 0.39 & 0.39 & 0.40 \\
\hline $\mathrm{P}_{2} \mathrm{O}_{5}$ & 0.22 & 0.59 & 0.22 & 0.24 & 0.21 & 0.24 & 0.23 & 0.18 & 0.22 & 0.22 & 0.18 & 0.21 & 0.13 & 0.13 \\
\hline Total & 100.03 & 100.97 & 100.11 & 100.78 & 100.14 & 100.00 & 100.00 & 101.13 & 100.51 & 101.41 & 100.31 & 101.32 & 101.16 & 101.53 \\
\hline \multicolumn{15}{|c|}{ CIPW norms: } \\
\hline Qtz & 15.9 & 14.4 & 16.1 & 12.9 & 14.7 & & & 0.4 & 2.4 & 3.5 & 1.3 & 2.2 & 2.1 & 2.1 \\
\hline Cor & 5.5 & 1.3 & 5.4 & 6.0 & 5.7 & & & & & & & & & \\
\hline Or & 6.0 & 13.7 & 6.8 & 6.0 & 6.0 & & & 1.4 & 2.2 & 2.8 & 1.9 & 2.3 & 2.3 & 2.3 \\
\hline $\mathrm{Ab}$ & 22.9 & 27.5 & 22.6 & 23.3 & 23.1 & & & 27.8 & 26.4 & 26.0 & 26.2 & 27.3 & 24.9 & 24.0 \\
\hline An & 16.5 & 16.1 & 16.0 & 17.6 & 17.3 & & & 28.8 & 24.6 & 24.2 & 27.7 & 25.9 & 25.8 & 26.3 \\
\hline $\mathrm{Di}$ & & & & & & & & 17.5 & 18.1 & 18.3 & 17.6 & 17.5 & 20.8 & 20.6 \\
\hline $\begin{array}{l}\text { Hy } \\
\text { Ol }\end{array}$ & 26.1 & 20.7 & 26.2 & 27.6 & 26.3 & & & 18.8 & 19.2 & 19.1 & 18.8 & 18.8 & 19.4 & 20.4 \\
\hline Mt & 2.1 & 1.7 & 2.1 & 2.3 & 2.1 & & & 2.0 & 2.2 & 2.1 & 2.0 & 2.1 & 2.1 & 2.0 \\
\hline $\mathrm{Ilm}$ & 3.4 & 3.4 & 3.4 & 3.6 & 3.5 & & & 3.2 & 3.9 & 3.9 & 3.4 & 3.7 & 2.5 & 2.5 \\
\hline Ap & 0.5 & 1.4 & 0.5 & 0.6 & 0.5 & & & 0.4 & 0.5 & 0.5 & 0.4 & 0.5 & 0.3 & 0.3 \\
\hline \multicolumn{15}{|l|}{ XRF: } \\
\hline $\mathrm{Nb}$ & 4.5 & 8.8 & 5.7 & 5.0 & 5.3 & 5.0 & 5.0 & & 6.7 & 6.4 & 5.1 & 5.9 & 3.3 & 3.0 \\
\hline $\mathrm{Zr}$ & 133.9 & 203.4 & 133.8 & 139.5 & 139.9 & 121.0 & 130.0 & & 141.4 & 141 & 115.1 & 133.4 & 99.4 & 97.7 \\
\hline $\mathrm{Y}$ & 25.7 & 26.6 & 26.5 & 28.4 & 24.9 & 34.0 & 26.0 & & 39.2 & 39.9 & 35.2 & 37.3 & 31.3 & 32.2 \\
\hline $\mathrm{Sr}$ & 135.7 & 131.6 & 131.3 & 140.7 & 138.0 & 129.0 & 150.0 & & 234.6 & 229.4 & 231.2 & 247.3 & 160.3 & 162.6 \\
\hline $\mathrm{Rb}$ & 37.5 & 61.2 & 36.5 & 37.8 & 37.6 & 23.0 & 20.0 & & 4.3 & 14.6 & 5.6 & 5.7 & 11.3 & 8.9 \\
\hline $\mathrm{Ga}$ & 24.0 & 23.5 & 24.5 & 26.2 & 25.0 & & & & 25.1 & 24.5 & 24.1 & 25.3 & 20.8 & 19.5 \\
\hline $\mathrm{Zn}$ & 271.4 & 272.4 & 274.4 & 306.4 & 281.3 & & & & 117.4 & 118.2 & 104.6 & 103.0 & 88.2 & 83.5 \\
\hline $\mathrm{Ni}$ & 122.7 & 111.0 & 139.0 & 127.9 & 125.3 & & & & 37.5 & 37.8 & 69.0 & 41.1 & 50.1 & 58.3 \\
\hline \multicolumn{15}{|l|}{ INAA: } \\
\hline $\mathrm{La}$ & 12.1 & 28.6 & 13.3 & 12.4 & 9.9 & & & 6.6 & 10.2 & 9.8 & 7.2 & 10.0 & 9.2 & 8.5 \\
\hline $\mathrm{Ce}$ & 31.0 & 59.0 & 41.0 & 36.0 & 30.0 & & & 18.0 & 25.6 & 30.0 & 21.4 & 26.3 & 25.1 & 18.4 \\
\hline Nd & 14.7 & 29.9 & 20.6 & 14.9 & 11.7 & & & & & & & & & \\
\hline Sm & 4.33 & 6.3 & 4.17 & 4.76 & 3.84 & & & 3.77 & 5.28 & 5.17 & 4.15 & 4.98 & & 3.53 \\
\hline Eu & 1.27 & 1.99 & 1.29 & 1.51 & 1.50 & & & 1.26 & 1.45 & 1.39 & 1.42 & 1.58 & 1.47 & 1.55 \\
\hline $\mathrm{Tb}$ & 0.86 & 1.36 & 0.98 & 1.11 & 0.88 & & & & & & & & & \\
\hline $\mathrm{Yb}$ & 2.71 & 4.41 & 2.53 & 2.87 & 1.80 & & & 3.07 & 3.50 & 3.56 & 2.86 & 3.21 & 2.93 & 2.84 \\
\hline Lu & 0.29 & 0.52 & 0.29 & 0.28 & 0.24 & & & 0.4 & 0.46 & 0.41 & 0.38 & 0.37 & 0.40 & 0.42 \\
\hline $\mathrm{Ta}$ & 0.33 & 0.62 & 0.32 & 0.34 & 0.32 & & & & & & & & & \\
\hline $\mathrm{Hf}$ & 4.6 & 5.5 & 2.9 & 3.7 & 3.4 & & & 3.6 & 4.5 & 4.5 & 3.8 & 5.0 & 3.0 & 3.2 \\
\hline Th & 1.40 & 6.40 & 1.62 & 1.87 & 1.80 & & & 0.69 & 1.60 & 1.20 & 1.20 & 1.50 & 1.30 & 1.50 \\
\hline W & 1.9 & 6.7 & 3.3 & 4.6 & 1.7 & & & & 2.2 & 4.0 & 3.2 & 1.5 & 2.7 & 2.2 \\
\hline $\mathrm{Sc}$ & 25.9 & 21.8 & 24.7 & 27.5 & 27.2 & & & 30.5 & 33.4 & 33.4 & 30.7 & 31.3 & 41.4 & 40.8 \\
\hline
\end{tabular}

Notes: Samples from the Naturalistic Plateau were collected during the Eltanin (EL) cruise; locations are shown in Figure 3 . Samples marked with an asterisk (*) are data taken from Coleman et al. (1982).

Middlemost et al., 1988). These probably represent low degree melts of the continental mantle lithosphere, as suggested by the presence of mantle phlogopite and high incompatible element ( $\mathrm{Ni}$ and $\mathrm{Cr}$ ) abundances (Middlemost et al., 1988).

Compared with Group I tholeiites, Group II tholeiites have higher ${ }^{87} \mathrm{Sr} /{ }^{86} \mathrm{Sr}$ ratios, show strong enrichment in highly incompatible elements, and generally have higher $\mathrm{La} / \mathrm{Nb}$ ratios (Fig. 8). One possibility is that Group II tholeiites represent crustal-contaminated Group I tholeiites. Simple mixing calculations show that contamination by approximately $10 \%-20 \%$ from the upper crust mimics quite well the observed incompatible element abundances of the Group II tholeiites (Fig. 14). Although there may be alternative explanations for the geochemical features of the Group II tholeiites, indirect support for the crustal contamination hypothesis is that the majority of the Rajmahal tholeiites fall on or slightly below the one atmosphere olivine-plagioclase-clinopyroxene cotectic, implying that most have been affected by lowpressure, upper crustal fractionation ( $<1-2 \mathrm{kbar})$.
The samples from Naturaliste Plateau and the Bunbury Basalt show varying degrees of enrichment in the large ion lithophile elements (LILE) over normal MORB. Although isotopic data were not available at the time of writing, these samples all appear to have strong continental lithosphere signatures, as suggested by their high $\mathrm{La} / \mathrm{Nb}$ ratios (Fig. 7) This is not inconsistent with the suggestion of Heezen and Tharp (1973) that the Naturaliste Plateau may consist of stretched continental lithosphere, near the ocean-continent divide.

\section{CONCLUSIONS}

Plate reconstructions are consistent with a KHP origin for the Kerguelen Plateau (possibly in a tectonic environment analogous to Iceland at the present day) and associated magmatism along the continental margin of India, Australia, and Antarctica. Furthermore, the geochemistry of the Kerguelen Plateau supports the hotspot hypothesis. Some plateau samples are consistent with a KHP source, whereas others 


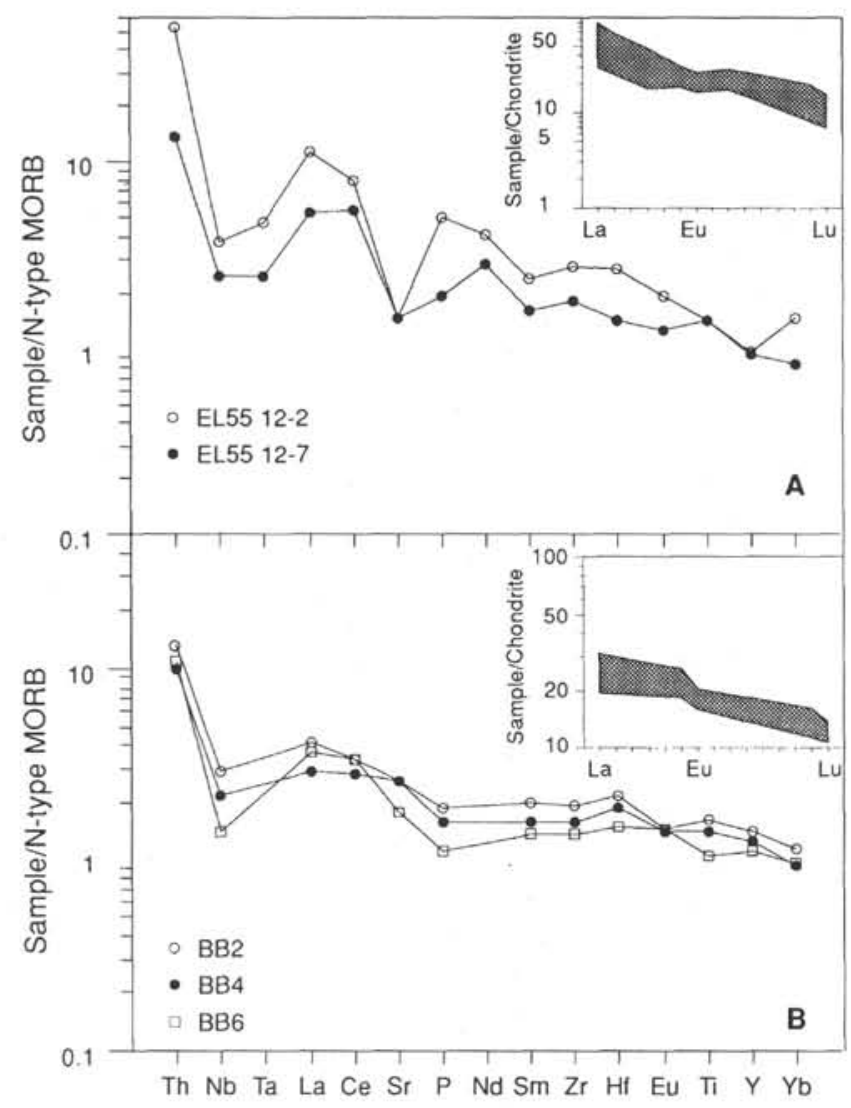

Figure 7. MORB-normalized plots and (insets) chondrite-normalized REE plots for (A) Eltanin dredge samples from the Naturaliste Plateau and (B) Bunbury Basalt tholeiites.

have compositions that are consistent with mixing between MORB and KHP mantle.

Samples from the central and southern parts of the plateau that have anomalously low ${ }^{206} \mathrm{~Pb} / 204 \mathrm{~Pb}$ and high $\mathrm{La} / \mathrm{Nb}$ ratios suggest contamination of the KHP source by components derived from the Gondwana lithosphere. This lithospheric component has its extreme expression in a tholeiite from Site 738 and may indicate that the southern end of the plateau is underlain by continental crust.

Compositional similarities between some Rajmahal tholeiites (Group I) and Kerguelen Plateau samples suggest a direct contribution to Lower Cretaceous continental volcanism by the KHP. Other examples (Rajmahal Group II tholeiites, Naturaliste Plateau, and Bunbury Basalt) show evidence for the substantial involvement of components derived from the continental lithosphere, possibly by crustal contamination of KHP magmas. The Indian lamprophyres may represent smalldegree melts of continental mantle lithosphere, with the KHP providing a possible heat source for this activity.

\section{ACKNOWLEDGMENTS}

We are grateful to Y. Bassias and L. Leclaire for supplying Marion Dufresne samples, J. Sheraton and N.C.N. Stephenson for Prince Charles Mountains alnoites, and the LamontDoherty Geological Observatory Deep-Sea Sample Repository for Eltanin samples from the Naturaliste Plateau. J. J. Mahoney and two anonymous reviewers are thanked for their constructive comments and Eva Barbu for editing the manuscript. Indian Ocean research at the University of Leicester is supported by NERC (Grant No. GST/02/257).

\section{REFERENCES}

Alibert, C., 1991. Mineralogy and geochemistry of a basalt from Site 738: implications for the tectonic history of the southernmost part of the Kerguelen Plateau. In Barron, J., Larsen, B., et al., Proc. ODP., Sci. Results, 119: College Station, TX (Ocean Drilling Program), 293-298.

Baksi, A. K., 1989. Elucidating the time of initiation and duration of volcanism for various Mesozoic-Tertiary flood basalt provinces. Bull.-N. M. Bur. Mines Miner. Res., No. 131. (Abstract).

Baksi, A. K., Barman, R. T., Paul, D. K., and Farrar, E., 1987. Widespread Early Cretaceous flood basalt volcanism in eastern India: geochemical data from the Rajmahal-Bengal-Sylhet traps. Chem. Geol., 63:133-141.

Barling, J., and Goldstein, S. L., 1990. Extreme isotopic variations in Heard Island lavas and the nature of mantle reservoirs. Nature, 348:59-62.

Barron, J., Larsen, B., et al., 1989. Proc. ODP, Init. Repts., 119: College Station, TX (Ocean Drilling Program).

Bassias, Y., Davies, H., Leclaire, L., and Weis, D., 1987. Basaltic basement and sedimentary rocks from the southern sector of the Kerguelen-Heard Plateau: new data and their Meso-Cenozoic paleogeographic and geodynamic implications. Bull. Mus. Natl. Hist. Nat., Sect. C, 9:367-403.

Biswas, B., 1963. Results of exploration for petroleum in the western part of the Bengal Basin, India. ECAFE Miner. Resour. Devl. Ser., $18: 241-250$.

Burgess, I. R., 1978. Geology and geochemistry of the Cretaceous Bunbury tholeiite suite, Perth Basin, Western Australia [B.Sc. honors thesis]. Univ. Western Australia, Perth.

Chattopadhyay, N., and Hashimi, S.,1984. The Sung valley alkalineultramafic carbonatite complex, East Khasi and Jainita Hills district, Meghalaya. Rec. Geol. Surv. India, 113:24-33.

Coffin, M. F., Davies, H. L., and Haxby, W. F., 1986. Structure of the Kerguelen Plateau province from SEASAT altimetry and seismic reflection data. Nature, 324:134-136.

Coleman, P. J., Michael, P. J., and Mutter, J. C., 1982. The origin of the Naturaliste Plateau, SE Indian Ocean: implications from dredged basalts. J. Geol. Soc. Aust., 29:457-468.

Davies, H. L., Sun, S.-S., Frey, F. A., Gautier, I., McCulloch, M. T., Price, R. C., Bassias, Y., Klootwijk, C. T., and Leclaire, L., 1989. Basalt basement from the Kerguelen Plateau and the trail of the Dupal plume. Contrib. Mineral Petrol., 103:457-469.

Davies, T. A., Luyendyk, B. P., et al., 1974. Init. Repts. DSDP, 26: Washington (U.S. Govt. Printing Office).

de Wit, M., Jeffrey, M., Bergh, H., and Nicolaysen, L., 1988. Geological map of sectors of Gondwana, reconstructed to their disposition at $150 \mathrm{Ma}$ : Tulsa, OK (AAPG).

Dietz, R. S., and Holden, J. C., 1970. Reconstruction of Pangea: breakup and dispersion of continents, Permian to present. $J$. Geophys. Res., 75:4939-4966.

Dosso, L., Bougault, H., Beuzart, P., Calvez, J.-Y., and Joron, J.-L., 1988. The geochemical structure of the South East Indian Ridge. Earth Planet. Sci. Lett., 88:47-59.

Dosso, L., Vidal, P., Cantagrel, J.-M., Lameyre, J., Marot, A., and Zimine, S., 1979. "Kerguelen: continental fragment or oceanic island?": petrology and isotopic geochemistry evidence. Earth Planet. Sci. Lett., 43:46-60.

Duncan, R. A., 1978. Geochronology of basalts from the Ninetyeast Ridge and continental dispersion in the eastern Indian Ocean. $J$. Volcanol. Geotherm. Res., 4:283-305.

Floyd, P. F., 1989. Geochemical features of intraplate oceanic plateau basalts. In Saunders, A. D., and Norry, M. J. (Eds.), Magmatism in the Ocean Basins. Geol Soc. Spec. Publ. (London), 42:215-230.

Gautier, I., Weis, D., Mennessier, J.-P., Vidal, P., Giret, A., and Loubet, M.,1990. Petrology and geochemistry of the Kerguelen archipelago basalts (South Indian Ocean): evolution of the mantle sources from ridge to intraplate position. Earth Planet. Sci. Lett., 100:59-76.

Gill, J. B., 1981. Orogenic Andesites and Plate Tectonics: BerlinHeidelberg-New York (Springer-Verlag).

Hamelin, B., Dupré, B., and Allègre, C. J., 1986. Pb-Sr-Nd isotopic data of Indian Ocean ridges: new evidence of large-scale mapping of mantle heterogeneities. Earth Planet. Sci. Lett., 76:288-298. 
Hart, S. R., 1984. A large-scale isotopic anomaly in the Southern Hemisphere mantle. Nature, 309:753-757.

Hayes, D. E., Frakes, L. A., et al., 1975. Init. Repts. DSDP, 28: Washington (U.S. Govt. Printing Office).

Hawkesworth, C. J., Kempton, P. D., Rogers, N. W., Ellam, R. M., and van Calsteren, P. W., 1990. Continental mantle lithosphere, and shallow level enrichment processes in the Earth's mantle. Earth Planet. Sci. Lett., 96:256-268.

Heezen, B. C., and Tharp, M., 1973. USNS Eltanin Cruise 55. Antarct. J. U.S., 8:137-141.

Houtz, R. E., Hayes, D. E., and Markl, R. J., 1977. Kerguelen Plateau bathymetry, sediment distribution and crustal structure. Mar. Geol., 25:95-130.

Jongsma, D., and Petkovic, P., 1977. The structure of the Naturaliste Plateau and Trough. APEA J., 17:3-12.

Kemp, E. M., 1969. Palynological examination of samples from the Beaver Lake area, Prince Charles Mountains, Antarctica. Bur. Miner. Resour. Aust. Rec., 1969/98.

Kent, D. V., and Gradstein, F. M., 1985. A Cretaceous and Jurassic geochronology. Geol. Soc. Am. Bull., 96:1419-1427.

Kent, R. W., 1991. Lithospheric uplift in eastern Gondwana: evidence for a long-lived mantle plume system? Geology, 19:19-23.

Leat, P. T., Thompson, R. N., Morrison, M. A., Hendry, G. L., and Dickin, A. P., 1990. Geochemistry of mafic lavas in the early Rio Grande Rift, Yarmony Mountain, Colorado, USA. Chem. Geol., 81:23-43.

Leclaire, L., Bassias, Y., Denis-Clocchiatti, M., Davies, H. L., Gautier, I., Gensous, B., Giannesini, P.-J., Patriat, P., Ségoufin, J., Tesson, M., and Wannesson, J. ,1987. Lower Cretaceous basalts and sediments from the Kerguelen Plateau. Geo-Mar. Lett., 7:169-176.

Li, Z. G., 1988. Structure, origine et évolution du plateau de Kerguelen [Ph.D. dissert.]. Univ. L. Pasteur, Strasbourg.

Luyendyck, B. P., and Rennick, W., 1977. Tectonic history of aseismic ridges in the eastern Indian Ocean. Geol. Soc. Am. Bull., 88:1347-1356.

McDougall, I., and Wellman, P.,1976. Potassium-argon ages for some Australian Mesozoic igneous rocks. J. Geol. Soc. Aust., 23:1-9.

McKenzie, D., and Bickle, M. J., 1988. The volume and composition of melt generated by extension of the lithosphere. J. Petrol., 29:625-679.

Mahoney, J. J., Macdougall, J. D., Lugmair, G. W., and Gopalan, K., 1983. Kerguelen hotspot source for Rajmahal Traps and Ninetyeast Ridge? Nature, 303:385-389.

Mahoney, J. J., Natland, J. H., White, W. M., Poreda, R., Bloomer, S. H., Fisher, R. L., and Baxter, A. N., 1989. Isotopic and geochemical provinces of the western Indian Ocean spreading centers. J. Geophys. Res., 94:4033-4052.

Mahoney, J. J., Nicollet, C., and Dupuy, C., in press. Madagascar flood basalts: tracking oceanic and continental sources. Earth Planet. Sci. Lett.

Mantovani, M.S.M., Marques, L. S., De Sousa, M. A., Civetta, L., Atalla, L., and Innocenti, F., 1985. Trace element and strontium isotope constraints on the origin and evolution of Parana continental flood basalts of Santa Catarina State (Southern Brazil). $J$. Petrol., 26:187-209.

Marsh, N. G., Saunders, A. D., Tarney, J., and Dick, H.J.B., 1980. Geochemistry of basalts from the Shikolu and Daito basins, Deep Sea Drilling Project Leg 58. In Klein, G. deV., Kobayashi, K., et al., Init. Rept. DSDP, 58: Washington (U.S. Govt. Printing Office), 805-842.

Marshall, J. F., and Lee, C. S., 1989. Basin framework and resource potential of the Abrolhos sub-basin. Aust. BMR Ann. Rept., 63-67.

Merriman, R. J., Taylor, P. N., and Morton, A. C., 1988. Petrochemistry and isotope geochemistry of early Palaeogene basalts forming the dipping reflector sequence SW of Rockall Plateau, NE Atlantic. In Morton, A. C., and Parson, L. M. (Eds.), Early Tertiary Volcanism and the Opening of the NE Atlantic. Geol. Soc. Spec. Publ. (London), 39:123-134.

Michard, A., Montigny, R., and Schlich, R., 1986. Geochemistry of the mantle beneath the Rodriguez Triple Junction and the SouthEast Indian Ridge. Earth Planet. Sci. Lett., 78:104-114.
Middlemost, E.A.K., Paul, D. K., and Fletcher, I. R., 1988. Geochemistry and mineralogy of the minette-lamproite association from the Indian Gondwanas. Lithos, 22:31-42.

Morgan, W. J., 1981. Hotspot tracks and the opening of the Atlantic and Indian oceans. In Emiliani, C. (Ed.), The Sea (Vol.7): The Oceanic Lithosphere: New York (Wiley-Interscience), 443-487.

Morton, A. C., and Taylor, P. N., 1987. Lead isotope evidence for the structure of the Rockall dipping-reflector passive margin. Nature, 326:381-383.

Munschy, M., and Schlich, R., 1987. Structure and evolution of the Kerguelen Plateau (Indian Ocean) deduced from seismic stratigraphic studies. Mar. Geol., 76:131-152.

Nelson, D. R., McCulloch, M. T., and Sun, S.-S., 1986. The origins of ultrapotassic rocks as inferred from $\mathrm{Sr}, \mathrm{Nd}$ and $\mathrm{Pb}$ isotopes. Geochim. Cosmochim. Acta, 50:231-245.

Paul, D. K., and Potts, P. J., 1981. Rare-earth abundances and origin of some Indian lamprophyres. Geol. Mag., 118:393-399.

Peirce, J. W., 1978. The northward motion of India since the Late Cretaceous. Geophys. J. R. Astron. Soc., 52:277-311.

Playford, P. E., Cockbain, A. E., and Low, G. H., 1976. Geology of the Perth Basin, Western Australia. Bull.-Geol. Surv. West. Aust., No. 124.

Powell, C. McA., Root, S. R., and Veevers, J. J., 1988. Pre-breakup continental extension in East Gondwanaland and the early opening of the eastern Indian Ocean. Tectonophysics, 155:261-283.

Ramsay, D. C., Colwell, J. B., Coffin, M. F., Davies, H. L., Hill, P. J., Pigram, C. J., and Stagg, H.M.J., 1986. New findings from the Kerguelen Plateau. Geology, 14:589-593.

Recq, M., Brefort, D., Malod, J., and Veinante, J.-L., 1990. The Kerguelen Isles (southern Indian Ocean): new results on deep structure from refraction profiles. Tectonophysics, 182:227-248.

Recq, M., and Charvis, P., 1986. A seismic refraction survey in the Kerguelen Isles, southern Indian Ocean. Geophys. J. R. Astron. Soc., 84:529-559.

Recq, M., Charvis, P., and Hirn, A., 1983. Preliminary results on the deep structure of the Kerguelen Ridge, from seismic refraction experiments. C. R. Acad. Sci., Ser. 2, 297:903-908.

Richards, M. A., Duncan, R. A., and Courtillot, V. E., 1989. Flood basalts and hotspot tracks: plume heads and tails. Science, 246:103-107.

Sarkar, A., Paul, D. K., Balasubrahmanyan, M. N., and Sengupta, N. R., 1980. Lamprophyres from the Indian Gondwanas-K-Ar ages and chemistry. J. Geol. Soc. India, 21:188-193

Saunders, A. D., Storey, M., Gibson, I. L., Leat, P., Hergt, J., and Thompson, R. N., in press. Chemical and isotopic constraints on the origin of the basalts from the Ninetyeast Ridge, Indian Ocean: results from Deep Sea Drilling Project Legs 22 and 26, and Ocean Drilling Program Leg 121. In Weissel, J., Peirce, J., Taylor, E., Alt, J., et al., Proc. ODP, Sci. Results, 121: College Station, TX (Ocean Drilling Program).

Saunders, A. D., Tarney, J., and Weaver, S. D., 1980. Transverse geochemical variations across the Antarctic Peninsula: implications for the genesis of calc-alkaline magmas. Earth Planet. Sci. Lett., 46:344-366.

Schlich, R., 1975. Structure et âge de l'Ocean Indien occidental. Mem. Hors Ser. Soc. Geol. Fr., 6:1-103.

1982. The Indian Ocean: aseismic ridges, spreading centers and oceanic basins. In Nairn, A.E.M., and Stehli, F. G. (Eds.), The Ocean Basins and Margins (Vol 6): The Indian Ocean: New York (Plenum Press), 51-147.

Schlich, R., Delteil, J. R., Moulin, J., Patriat, P., and Guillaume, R., 1971. Mise en evidence d'une sedimentation de marge continentale sur le plateau de Kerguelen-Heard. C. R. Acad. Sci., Ser. D, 272:2060-2065.

Schlich, R., Wise, S. W., Jr., et al., 1989. Proc. ODP, Init. Repts., 120: College Station, TX (Ocean Drilling Program).

Schubert, G., and Sandwell, D., 1989. Crustal volumes of the continents and of oceanic and continental submarine plateaus. Earth Planet. Sci. Lett., 92:234-246.

Sengupta, S., 1988. Upper Gondwana stratigraphy and palaeobotany of Rajmahal Hills, Bihar (India). Palaeontologica India. Geol. Surv. India Monogr., No. 48 (new ser.).

1966. Geological and geophysical studies in western part of Bengal Basin, India. AAPG Bull., 50:1001-1017. 
Storey, M., Mahoney, J. J., Kroenke, L., and Saunders, A. D., 1991. Are oceanic plateaus sites of komatiite formation? Geology, 19:376-379.

Storey, M., Saunders, A. D., Tarney, J., Gibson, I. L., Norry, M. J., Thirlwall, M. F., Leat, P., Thompson, R. N., and Menzies, M. A., 1989. Contamination of Indian Ocean asthenosphere by the Kerguelen-Heard mantle plume. Nature, 338:574-576.

Storey, M., Saunders, A. D., Tarney, J., Leat, P., Thirlwall, M. F., Thompson, R.N., Menzies, M. A., and Marriner, G. F., 1988. Geochemical evidence for plume-mantle interactions beneath Kerguelen and Heard islands, Indian Ocean. Nature, 336:371374.

Sun, S.-S., and McDonough, W. F., 1989. Chemical and isotopic systematics of oceanic basalts: implications for mantle composition and processes. In Saunders, A. D., and Norry, M. J. (Eds.), Magmatism in the Ocean Basins. Geol. Soc. Spec. Publ. (London), 42:313-345.

Talukdar, S. C., 1967. Rhyolites and alkali basalts from the Sylhet Trap, Khasi Hills, Assam. Curr. Sci., 36:238-239.

Talukdar, S. C., and Murthy, M.V.N.,1970. The Sylhet Traps, their tectonic history, and their bearing on problems of Indian flood basalt provinces. Bull. Volcanol., 35:602-618.

Taylor, S. R., and McLennan, S. M., 1985. The Continental Crust: Its Composition and Evolution: Oxford (Blackwell Scientific Publications).

Viereck, L. G., Taylor, P. N., Parson, L. M., Morton, A. C., Hertogen, J., Gibson, I. L., and the ODP Leg 104 Scientific Party,
1988. Origin of the Palaeogene Vøring Plateau volcanic sequence. In Morton, A. C., and Parson, L. M. (Eds.), Early Tertiary Volcanism and the Opening of the NE Atlantic. Geol Soc. Spec. Publ. (London), 39:69-83.

Walker, K. R., and Mond, A., 1971. Mica lamprophyre (alnoite) from Radok Lake, Prince Charles Mountains, Antarctica. BMR Rec., 1971:108.

Weaver, B. L., Marsh, N. G., and Tarney, J., 1983. Trace element geochemistry of basaltic rocks recovered at Site 516, Rio Grande Rise, Deep Sea Drilling Project. In Barker, P. F., Carlson, R. L., Johnson, D. A., et al., Init. Repts. DSDP, 72: Washington (U.S. Govt. Printing Office), 451-456.

Weis, D., Bassias, Y., Gautier, I., and Mennessier, J.-P., 1989. DUPAL anomaly in existence $115 \mathrm{Ma}$ ago: evidence from isotopic study of the Kerguelen Plateau (South Indian Ocean). Geochim. Cosmochim. Acta, 53:2125-2131.

White, R. W., and McKenzie, D. P., 1989. Magmatism at rift zones: the generation of volcanic continental margins and flood basalts. J. Geophys. Res., 94:7685-7729.

Date of initial receipt: 2 March 1990

Date of acceptance: 6 February 1991

Ms 120B-118 


\section{STOREY ET AL.}

Table 3. Major and trace element analyses of Rajmahal basalts, India.

\begin{tabular}{|c|c|c|c|c|c|c|c|c|c|c|c|c|c|}
\hline Sample & RB88/2 & RB88/10 & RB88/15 & $\mathrm{RB} 88 / 20$ & $\mathrm{RB} 88 / 21$ & RB88/29 & $\mathrm{RB} 88 / 30$ & RB88/34 & RB88/35 & RB88/42 & BH-1 & BH-6 & TT-3 \\
\hline \multicolumn{14}{|c|}{ Major elements: } \\
\hline $\mathrm{SiO}_{2}$ & 53.20 & 52.30 & 51.80 & 52.90 & 50.70 & 52.90 & 51.40 & 57.30 & 53.00 & 51.10 & 54.02 & 52.6 & 52.09 \\
\hline $\mathrm{TiO}_{2}$ & 1.70 & 1.77 & 2.10 & 1.44 & 1.76 & 1.66 & 1.78 & 1.01 & 1.82 & 1.78 & 1.75 & 1.65 & 1.71 \\
\hline $\mathrm{Al}_{2} \mathrm{O}_{3}$ & 14.90 & 15.00 & 15.50 & 15.70 & 14.60 & 14.70 & 15.10 & 15.00 & 14.90 & 15.00 & 14.67 & 14.7 & 15 \\
\hline $\mathrm{Fe}_{2} \mathrm{O}_{3}$ & 11.00 & 11.90 & 12.10 & 9.90 & 11.90 & 10.70 & 12.00 & 8.80 & 11.40 & 12.10 & 10.92 & 10.7 & 12.01 \\
\hline $\mathrm{MnO}^{\circ}$ & 0.17 & 0.19 & 0.15 & 0.16 & 0.18 & 0.16 & 0.19 & 0.12 & 0.18 & 0.18 & 0.17 & 0.17 & 0.2 \\
\hline $\mathrm{MgO}$ & 6.10 & 6.50 & 5.30 & 7.10 & 6.60 & 6.00 & 6.20 & 8.00 & 5.50 & 6.80 & 5.91 & 5.9 & 6.48 \\
\hline $\mathrm{CaO}$ & 9.50 & 10.60 & 10.10 & 9.80 & 10.50 & 9.20 & 10.8 & 6.30 & 8.90 & 10.80 & 9.45 & 9.2 & 10.76 \\
\hline $\mathrm{Na}_{2} \mathrm{O}$ & 2.30 & 2.60 & 3.00 & 2.50 & 2.30 & 2.10 & 2.60 & 2.90 & 2.60 & 2.50 & 2.79 & 2.30 & 2.83 \\
\hline $\mathrm{K}_{2} \mathrm{O}$ & 0.940 & 0.270 & 0.250 & 0.560 & 0.190 & 0.950 & 0.190 & 0.250 & 1.170 & 0.150 & 1.177 & 1.120 & 0.150 \\
\hline $\mathrm{P}_{2} \mathrm{O}_{5}$ & 0.220 & 0.190 & 0.230 & 0.200 & 0.150 & 0.240 & 0.190 & 0.120 & 0.260 & 0.190 & 0.231 & 0.230 & 0.185 \\
\hline Total & 99.90 & 101.41 & 100.49 & 100.28 & 98.92 & 98.57 & 100.56 & 99.74 & 99.53 & 100.52 & 101.09 & 98.49 & 101.42 \\
\hline \multicolumn{14}{|c|}{ CIPW norms: } \\
\hline Qtz & 5.64 & 3.02 & 2.89 & 3.76 & 3.27 & 7.05 & 2.50 & 10.31 & 4.68 & 1.92 & 3.90 & 5.36 & 1.81 \\
\hline Or & 5.56 & 1.60 & 1.48 & 3.31 & 1.12 & 5.61 & 1.12 & 1.48 & 6.91 & 0.89 & 6.96 & 6.62 & 0.89 \\
\hline $\mathrm{Ab}$ & 19.46 & 22.00 & 25.39 & 21.16 & 19.46 & 17.77 & 22.00 & 24.54 & 22.00 & 21.16 & 23.61 & 19.46 & 23.95 \\
\hline An & 27.56 & 28.47 & 28.10 & 29.97 & 28.96 & 27.89 & 28.98 & 27.18 & 25.54 & 29.27 & 24.04 & 26.49 & 27.79 \\
\hline Di & 14.90 & 18.82 & 16.97 & 14.14 & 18.21 & 13.30 & 19.25 & 2.67 & 13.97 & 18.96 & 17.55 & 14.51 & 20.07 \\
\hline Hy & 20.32 & 20.52 & 18.05 & 22.15 & 21.07 & 20.50 & 19.66 & 29.14 & 19.62 & 21.45 & 18.35 & 19.68 & 20.12 \\
\hline $\mathrm{Mt}$ & 1.90 & 2.05 & 2.09 & 1.71 & 2.05 & 1.85 & 2.07 & 1.52 & 1.97 & 2.09 & 1.88 & 1.85 & 2.07 \\
\hline Ilm & 3.23 & 3.36 & 3.99 & 2.73 & 3.34 & 3.15 & 3.38 & 1.92 & 3.46 & 3.38 & 3.32 & 3.13 & 3.25 \\
\hline Ap & 0.51 & 0.44 & 0.53 & 0.46 & 0.35 & 0.56 & 0.44 & 0.28 & 0.60 & 0.44 & 0.54 & 0.53 & 0.43 \\
\hline \multicolumn{14}{|l|}{ XRF: } \\
\hline $\mathrm{Nb}$ & 8.7 & & 6.4 & 5.7 & 6.5 & 7.6 & 5.7 & & 10.2 & 4.6 & 8.4 & 9.9 & \\
\hline $\mathrm{Zr}$ & 160.6 & 107.4 & 120.8 & 118.2 & 106.8 & 160.3 & 99.8 & 49.9 & 170.4 & 93.9 & 159.7 & 160.3 & 108.3 \\
\hline Y & 35.3 & 30.6 & 30.9 & 25.7 & 31.5 & 33.8 & 30.6 & 26.7 & 36.8 & 29.6 & 34.8 & 33.9 & 31.0 \\
\hline $\mathrm{Sr}$ & 332.2 & 249.1 & 264.4 & 328.7 & 245.2 & 322.8 & 227.1 & 148.2 & 324.3 & 223.3 & 325.3 & 321.4 & 237.9 \\
\hline $\mathrm{Rb}$ & 22.6 & 7.2 & 2.0 & 17.3 & 1.9 & 31.7 & 6.5 & 5.9 & 32.8 & 4.1 & 23.1 & 22.1 & 0.3 \\
\hline $\mathrm{Ga}$ & 22.6 & 22.8 & 24.8 & 22.5 & 22.5 & 21.7 & 22.8 & 22.6 & 21.8 & 24.0 & 21.6 & 21.1 & 22.2 \\
\hline $\mathrm{Zn}$ & 101.5 & 106.7 & 107.6 & 91.6 & 100.9 & 103.6 & 103.3 & 138.4 & 105.5 & 104.7 & 94.6 & 105.0 & 93.7 \\
\hline $\mathrm{Ni}$ & 31.6 & 69.4 & 51.7 & 37.4 & 63.6 & 34.1 & 59.2 & 147.4 & 29.6 & 65.4 & 17.7 & 29.5 & 68.6 \\
\hline V & 222.3 & & 324.0 & 208.6 & 271.3 & 230.5 & 265.3 & 130.0 & 223.2 & 271.8 & & 229.4 & \\
\hline $\mathrm{Cr}$ & 155.4 & & 105.0 & 295.2 & 229.1 & 155.6 & 207.9 & 672.5 & 119.4 & 415.0 & & 187.1 & \\
\hline $\mathrm{Ba}$ & 316.4 & & 122.7 & 201.5 & 79.3 & 306.5 & 55.6 & 63.5 & 371.9 & 44.4 & & 308.6 & \\
\hline $\mathrm{La}$ & 18.6 & & 7.6 & 10.8 & 9.0 & 18.3 & 7.0 & 5.6 & 19.2 & 6.5 & & 15.3 & \\
\hline $\mathrm{Ce}$ & 44.6 & & 20.5 & 31.7 & 18.2 & 43.2 & 15.5 & 8.0 & 41.7 & 14.0 & & 38.1 & \\
\hline $\mathrm{Nd}$ & 23.4 & & 15.8 & 17.3 & 12.3 & 22.2 & 11.1 & 5.5 & 25.3 & 13.6 & & 21.3 & \\
\hline \multicolumn{14}{|l|}{ INAA: } \\
\hline $\mathrm{La}$ & 16.4 & 7.9 & 8.8 & 11.9 & 7.4 & & 7 & 3.9 & & & & & 7.5 \\
\hline $\mathrm{Ce}$ & 38.2 & 21.1 & 22.8 & 27.7 & & & 18.9 & 8.3 & & & & & 21.6 \\
\hline $\mathrm{Nd}$ & 21.0 & 13.7 & 13.1 & 13.8 & 11.7 & & & & & & & & 14.1 \\
\hline $\mathrm{Sm}$ & 4.69 & 3.87 & 4.11 & 3.72 & 3.80 & & 3.75 & 2.52 & & & & & 3.98 \\
\hline $\mathrm{Eu}$ & 1.50 & 1.39 & 1.37 & 1.35 & 1.50 & & 1.24 & 1.02 & & & & & 1.34 \\
\hline $\mathrm{Tb}$ & 0.68 & 0.86 & 0.72 & 0.56 & 0.74 & & 0.76 & 0.70 & & & & & 0.80 \\
\hline $\mathrm{Yb}$ & 2.66 & 2.86 & 2.80 & 2.24 & 2.99 & & 2.67 & 1.94 & & & & & 3.12 \\
\hline $\mathrm{Lu}$ & 0.44 & 0.38 & 0.41 & 0.34 & 0.37 & & 0.39 & 0.27 & & & & & 0.42 \\
\hline $\mathrm{Ta}$ & 0.55 & 0.46 & 0.46 & 0.40 & 0.38 & & 0.34 & 0.15 & & & & & 0.47 \\
\hline Hf & 4.40 & 2.97 & 3.50 & 3.03 & 3.40 & & 2.9 & 1.48 & & & & & 3.02 \\
\hline Th & 2.70 & 0.71 & 0.71 & 2.20 & 0.45 & & 0.53 & 0.49 & & & & & 0.92 \\
\hline W & 3.1 & 1.8 & 4.1 & 2.3 & 3.8 & & 4.9 & 2.6 & & & & & 4.1 \\
\hline Sc & 30.8 & 35.7 & 40.5 & 28.8 & 34.2 & & 37.0 & 14.5 & & & & & 37.9 \\
\hline
\end{tabular}

Note: See Figure 4 for locations. 
Table 3 (continued).

\begin{tabular}{|c|c|c|c|c|c|c|c|c|c|c|c|c|}
\hline Sample & LH-1 & GP-1 & BL-3 & $\mathrm{KP}-4$ & KP-6 & KP-7 & NP-1 & NP-4 & NP-7 & NP-9 & LA-2 & LA-6 \\
\hline \multicolumn{13}{|c|}{ Major elements: } \\
\hline $\mathrm{SiO}_{2}$ & 50.7 & 54.1 & & 51.4 & 52.1 & 51.3 & 51.5 & & 52.30 & 51.80 & 52.60 & 49.40 \\
\hline $\mathrm{TiO}_{2}$ & 1.55 & 1.74 & & 2.21 & 1.49 & 2.22 & 1.76 & & 1.82 & 1.69 & 2.09 & 2.18 \\
\hline $\mathrm{Al}_{2} \mathrm{O}_{3}$ & 15.2 & 14.7 & & 14.6 & 15.6 & 14.7 & 14.4 & & 15.00 & 14.40 & 13.70 & 14.00 \\
\hline $\mathrm{Fe}_{2} \mathrm{O}_{3}$ & 11.3 & 10.9 & & 13.4 & 11.6 & 13.1 & 12.4 & & 11.70 & 11.60 & 12.30 & 12.80 \\
\hline $\mathrm{MnO}^{3}$ & 0.2 & 0.17 & & 0.2 & 0.2 & 0.2 & 0.2 & & 0.20 & 0.19 & 0.18 & 0.20 \\
\hline $\mathrm{MgO}$ & 6 & 5.9 & & 5.9 & 6.2 & 5.8 & 6.4 & & 6.60 & 6.40 & 5.70 & 5.90 \\
\hline $\mathrm{CaO}$ & 11.1 & 9.4 & & 10.7 & 11.8 & 10.8 & 11 & & 10.40 & 10.30 & 10.00 & 10.60 \\
\hline $\mathrm{Na}_{2} \mathrm{O}$ & 2.50 & 2.30 & & 2.5 & 2.5 & 2.6 & 2.5 & & 2.50 & 2.50 & 2.30 & 2.40 \\
\hline $\mathrm{K}_{2} \mathrm{O}$ & 0.170 & 1.100 & & 0.230 & 0.190 & 0.250 & 0.210 & & 0.270 & 0.310 & 0.370 & 0.290 \\
\hline $\mathrm{P}_{2} \mathrm{O}_{5}$ & 0.160 & 0.220 & & 0.210 & 0.150 & 0.220 & 0.180 & & 0.190 & 0.190 & 0.230 & 0.250 \\
\hline Total & 98.93 & 100.50 & & 101.29 & 101.86 & 101.14 & 100.55 & & 101.04 & 99.49 & 99.49 & 98.14 \\
\hline \multicolumn{13}{|c|}{ CIPW norms: } \\
\hline Qtz & 2.47 & 6.64 & & 3.18 & 2.28 & 2.72 & 2.63 & & 3.72 & 3.83 & 7.12 & 2.34 \\
\hline Or & 1.00 & 6.50 & & 1.36 & 1.12 & 1.48 & 1.24 & & 1.60 & 1.83 & 2.19 & 1.71 \\
\hline $\mathrm{Ab}$ & 21.16 & 19.46 & & 21.16 & 21.16 & 22.00 & 21.16 & & 21.16 & 21.16 & 19.46 & 20.31 \\
\hline An & 29.76 & 26.55 & & 27.94 & 30.79 & 27.71 & 27.46 & & 28.92 & 27.16 & 25.97 & 26.58 \\
\hline Di & 19.99 & 15.34 & & 19.68 & 22.06 & 20.22 & 21.38 & & 17.61 & 18.67 & 18.29 & 20.14 \\
\hline Hy & 18.25 & 19.40 & & 19.87 & 18.23 & 18.94 & 19.7 & & 21.04 & 20.08 & 18.75 & 18.89 \\
\hline $\mathrm{Mt}$ & 1.95 & 1.88 & & 2.31 & 2.00 & 2.26 & 2.14 & & 2.02 & 2.00 & 2.12 & 2.21 \\
\hline $\mathrm{Ilm}$ & 2.94 & 3.30 & & 4.20 & 2.83 & 4.22 & 3.34 & & 3.46 & 3.21 & 3.97 & 4.14 \\
\hline Ap & 0.37 & 0.51 & & 0.49 & 0.35 & 0.51 & 0.42 & & 0.44 & 0.44 & 0.53 & 0.58 \\
\hline \multicolumn{13}{|l|}{ XRF: } \\
\hline $\mathrm{Nb}$ & 3.9 & 9.3 & 6.3 & 6.5 & 4.5 & 7.5 & 5.5 & 7.0 & 4.9 & 6.7 & 6.7 & \\
\hline $\mathrm{Zr}$ & 95.2 & 159.1 & 84.8 & 127.0 & 83.8 & 131.3 & 101.6 & 118.1 & 102.5 & 107.3 & 114.5 & \\
\hline $\mathrm{Y}$ & 29.5 & 33.6 & 26.8 & 35.0 & 26.6 & 35.8 & 31.7 & 36.4 & 30.6 & 30.5 & 33.2 & \\
\hline $\mathrm{Sr}$ & 233.6 & 347.4 & 231.8 & 236.3 & 232.7 & 240.7 & 230.2 & 304.4 & 233.0 & 254.3 & 219.3 & \\
\hline $\mathrm{Rb}$ & 4.0 & 30.2 & 3.9 & 4.2 & 5.0 & 6.1 & 2.9 & 8.1 & 2.5 & 6.5 & 5.9 & \\
\hline $\mathrm{Ga}$ & 22.3 & 23.0 & 21.2 & 22.5 & 21.1 & 25.3 & 21.9 & 22.0 & 23.4 & 22.8 & 19.2 & \\
\hline $\mathrm{Zn}$ & 95 & 101.7 & 91.8 & 110.2 & 88.9 & 111.3 & 101.9 & 114.2 & 105.8 & 97.7 & 102.6 & \\
\hline $\mathrm{Ni}$ & 76.8 & 20.3 & 66.6 & 67.8 & 68.6 & 82.3 & 54.8 & 60.3 & 58.5 & 53.5 & 62.8 & \\
\hline V & 277.0 & 235.8 & 274.4 & 294.4 & 267.1 & 305.5 & 287.9 & 328.2 & 265.9 & 255.1 & 304.0 & \\
\hline $\mathrm{Cr}$ & 206.3 & 172.2 & 241.6 & 128.4 & 220.5 & 132.9 & 167.3 & 148.6 & 237.4 & 230.9 & 165.3 & \\
\hline $\mathrm{Ba}$ & 82.1 & 265.3 & 97.6 & 89.3 & 92.4 & 102.8 & 143.4 & 246.0 & 74.6 & 83.0 & 80.3 & \\
\hline $\mathrm{La}$ & 5.1 & 16.6 & 7.2 & 10.3 & 5.0 & 8.7 & 5.8 & 11.4 & 7.3 & 7.0 & 5.4 & \\
\hline $\mathrm{Ce}$ & 17.5 & 39.1 & 11.8 & 26.1 & 19.0 & 23.9 & 21.1 & 23.7 & 22.2 & 22.2 & 18.2 & \\
\hline Nd & 10.2 & 21.8 & 9.5 & 14.5 & 10.4 & 16.8 & 12.9 & 16.9 & 11.9 & 11.3 & 16.8 & \\
\hline \multicolumn{13}{|l|}{ INAA: } \\
\hline $\mathrm{La}$ & & & & & & & & & & 7.8 & & \\
\hline $\mathrm{Ce}$ & & & & & & & & & & 22.0 & & \\
\hline Nd & & & & & & & & & & 13.5 & & \\
\hline $\mathrm{Sm}$ & & & & & & & & & & 4.06 & & \\
\hline $\mathrm{Eu}$ & & & & & & & & & & 1.39 & & \\
\hline $\mathrm{Tb}$ & & & & & & & & & & 0.80 & & \\
\hline $\mathrm{Yb}$ & & & & & & & & & & 3.26 & & \\
\hline $\mathrm{Lu}$ & & & & & & & & & & 0.40 & & \\
\hline $\mathrm{Ta}$ & & & & & & & & & & 0.46 & & \\
\hline Hf & & & & & & & & & & 2.70 & & \\
\hline Th & & & & & & & & & & 0.75 & & \\
\hline W & & & & & & & & & & 3.8 & & \\
\hline $\mathrm{Sc}$ & & & & & & & & & & 35.7 & & \\
\hline
\end{tabular}




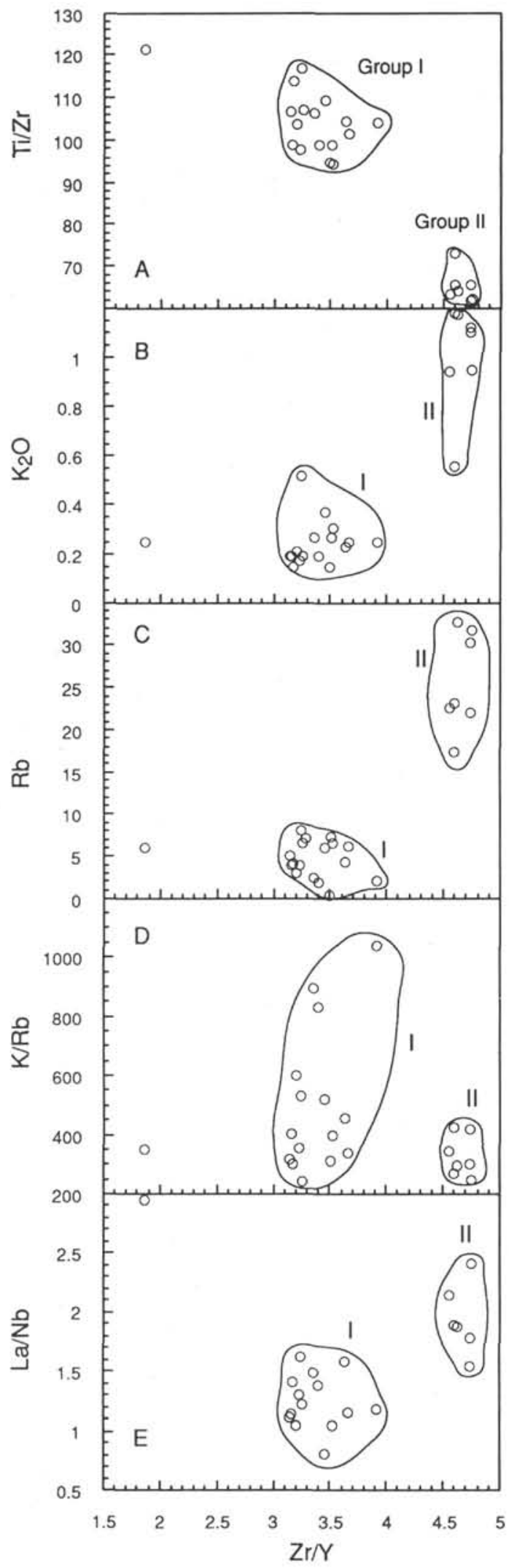

Figure 8. The variation of the $\mathrm{Zr} / \mathrm{Y}$ ratio in Rajmahal samples vs. (A) $\mathrm{Ti} / \mathrm{Zr}$, (B) $\mathrm{K}_{2} \mathrm{O} \%$, (C) $\mathrm{Rb}$ (ppm), (D) $\mathrm{K} / \mathrm{Rb}$, and (E) $\mathrm{La} / \mathrm{Nb}$.

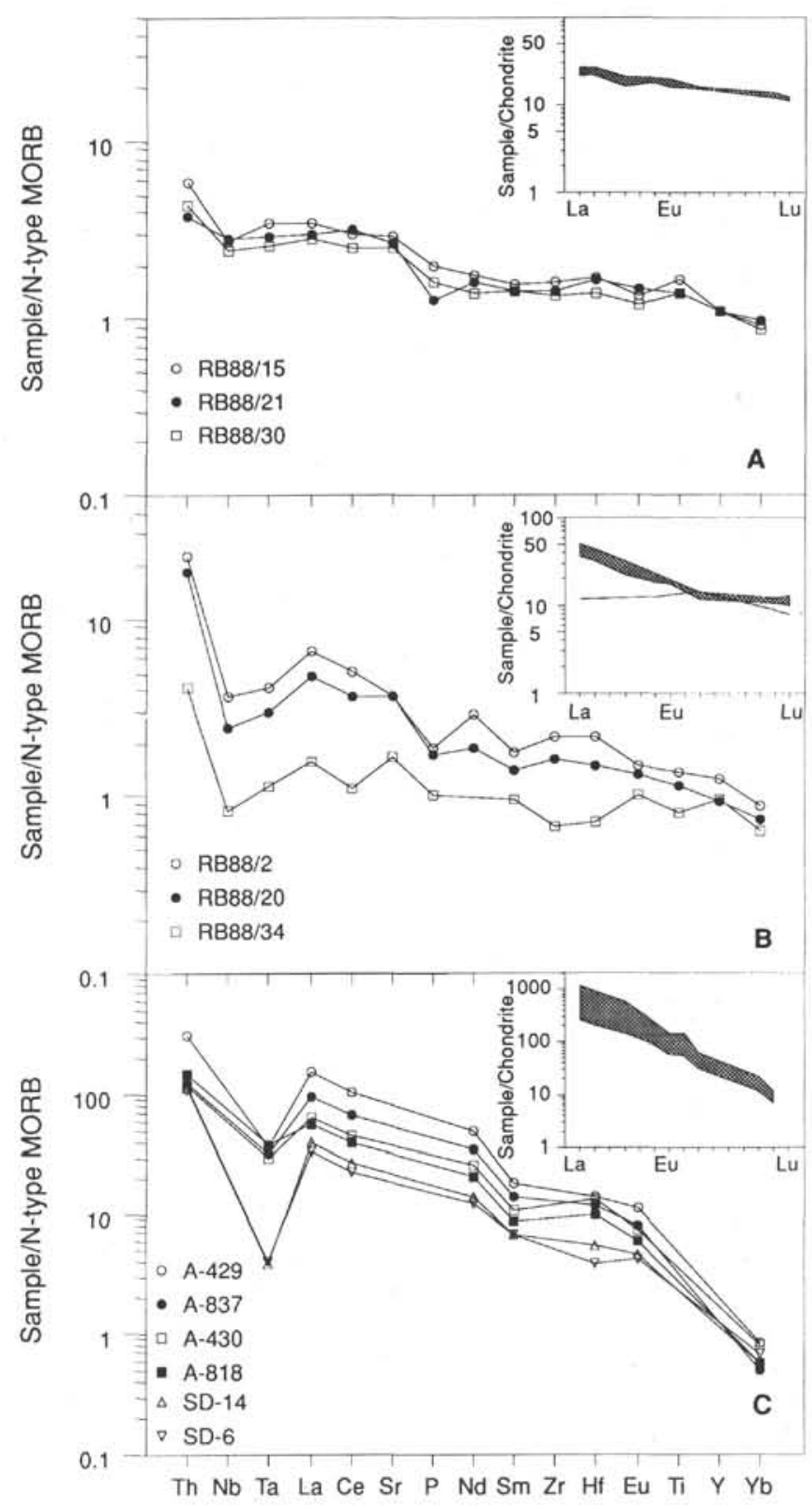

Figure 9. MORB-normalized plots and chondrite-normalized (inset) REE plots for (A) Group I Rajmahal tholeiites, (B) Group II Rajmahal tholeiites, and (C) Lower Cretaceous Indian lamprophyres; data from Paul and Potts (1981). 
Table 4. Major and trace element analyses of alnoites from the Prince Charles Mountains, Antarctica.

\begin{tabular}{|c|c|c|}
\hline Sample & D15 & D18 \\
\hline \multicolumn{3}{|c|}{ Major elements: } \\
\hline $\mathrm{SiO}_{2}$ & 37.14 & 37.35 \\
\hline $\mathrm{TiO}_{2}$ & 2.23 & 2.42 \\
\hline $\mathrm{Al}_{2} \mathrm{O}_{3}$ & 9.47 & 10.55 \\
\hline $\mathrm{Fe}_{2} \mathrm{O}_{3}$ & 12.11 & 12.54 \\
\hline $\mathrm{MnO}$ & 0.20 & 0.22 \\
\hline $\mathrm{MgO}$ & 16.11 & 13.88 \\
\hline $\mathrm{CaO}$ & 16.36 & 15.40 \\
\hline $\mathrm{Na}_{2} \mathrm{O}$ & 2.08 & 2.46 \\
\hline $\mathrm{K}_{2} \mathrm{O}$ & 3.29 & 3.51 \\
\hline $\mathrm{P}_{2} \mathrm{O}_{5}$ & 0.88 & 1.30 \\
\hline Total & 99.87 & 99.63 \\
\hline \multicolumn{3}{|c|}{ CIPW norms: } \\
\hline An & 6.8 & 7.4 \\
\hline Lu & 15.3 & 16.3 \\
\hline $\mathrm{Ne}$ & 9.5 & 11.3 \\
\hline Di & & 1.8 \\
\hline Cs & 22.7 & 18.5 \\
\hline $\mathrm{Ol}$ & 39.1 & 34.0 \\
\hline Mt & 2.1 & 2.2 \\
\hline $\mathrm{Ilm}$ & 4.2 & 4.6 \\
\hline Ap & 2.0 & 3.0 \\
\hline \multicolumn{3}{|l|}{ XRF: } \\
\hline $\mathrm{Nb}$ & 118.0 & 165.1 \\
\hline $\mathrm{Zr}$ & 235.7 & 437.7 \\
\hline $\mathbf{Y}$ & 37.5 & 48.7 \\
\hline $\mathrm{Sr}$ & 1003.9 & 1115.3 \\
\hline $\mathrm{Rb}$ & 129.9 & 148.0 \\
\hline Th & 10.6 & 11.7 \\
\hline $\mathrm{Zn}$ & 85.2 & 83.5 \\
\hline $\mathrm{Ni}$ & 281.2 & 238.9 \\
\hline \multicolumn{3}{|l|}{ INAA: } \\
\hline $\mathrm{La}$ & 89.0 & 96.0 \\
\hline $\mathrm{Ce}$ & 223.0 & 225.0 \\
\hline Nd & 99.0 & 106.0 \\
\hline Sm & 10.2 & 11.0 \\
\hline $\mathrm{Eu}$ & 2.99 & 3.12 \\
\hline $\mathrm{Tb}$ & 1.58 & 1.85 \\
\hline $\mathrm{Yb}$ & 2.35 & 3.28 \\
\hline $\mathrm{Lu}$ & 0.21 & 0.38 \\
\hline $\mathrm{Ta}$ & 9.5 & 9.8 \\
\hline Hf & 6.1 & 9.2 \\
\hline Th & 14.3 & 12.3 \\
\hline W & 21.0 & 13.5 \\
\hline $\mathrm{Sc}$ & 24.6 & 30.2 \\
\hline
\end{tabular}

Note: See Figure 1 for location.

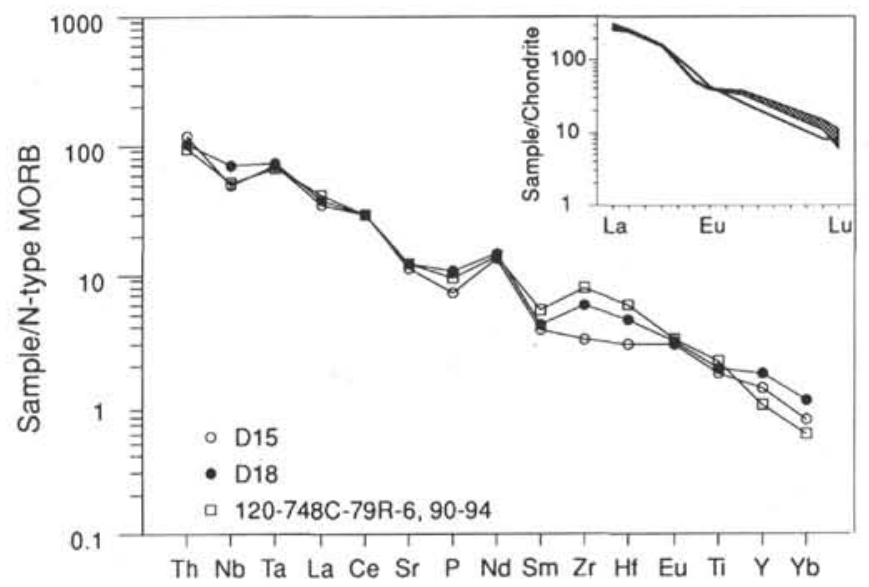

Figure 10. MORB-normalized plots and chondrite-normalized (inset) REE plots for Prince Charles Mountains alnoites. Note the strong similarity with the Albian alkali basalt from Site 748 . 


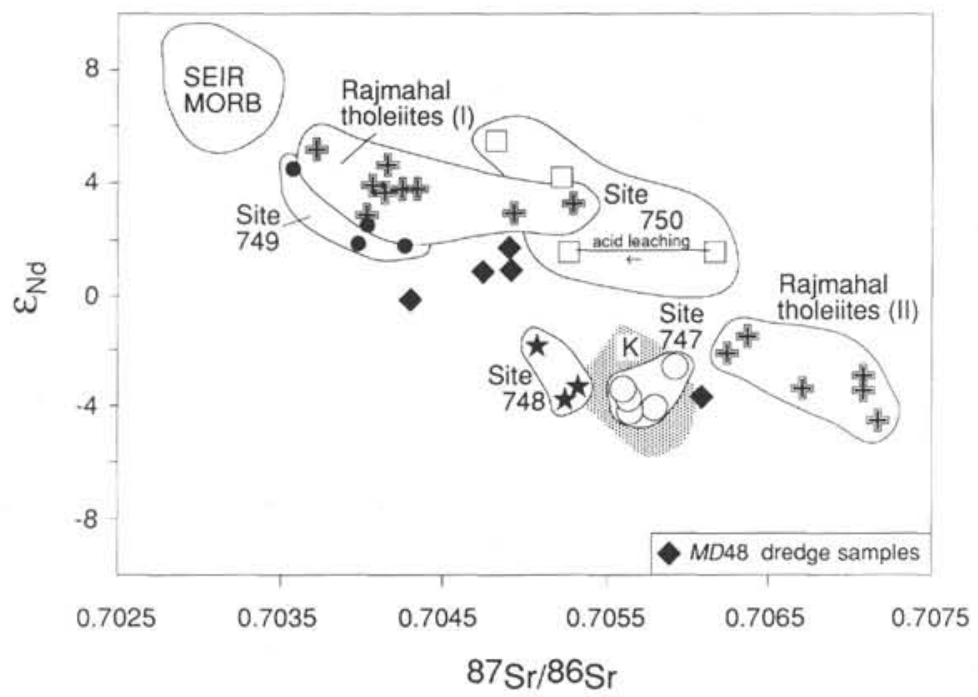

Figure 11. ${ }^{87} \mathrm{Sr} /{ }^{86} \mathrm{Sr}$ vs. $\varepsilon_{\mathrm{Nd}}$ for Kerguelen Plateau (data from Alibert, in press; Salters et al., this volume; M. Storey, unpubl. data) and Rajmahal basalts (data from Mahoney et al., 1983; M. Storey, unpubl. data). Data corrected for T $\sim 110$ m.y., except for Site 748, where T 90 m.y. Site 750 sample acid leached in $6 \mathrm{M}$ $\mathrm{HCl}$. Stippled area represents most enriched basalts from Kerguelen Island (Storey et al., 1988, and references cited therein). Data for normal Southeast Indian Ridge (SEIR) MORB from Dosso et al. (1988), Hamelin et al. (1986), and Michard et al. (1986). 


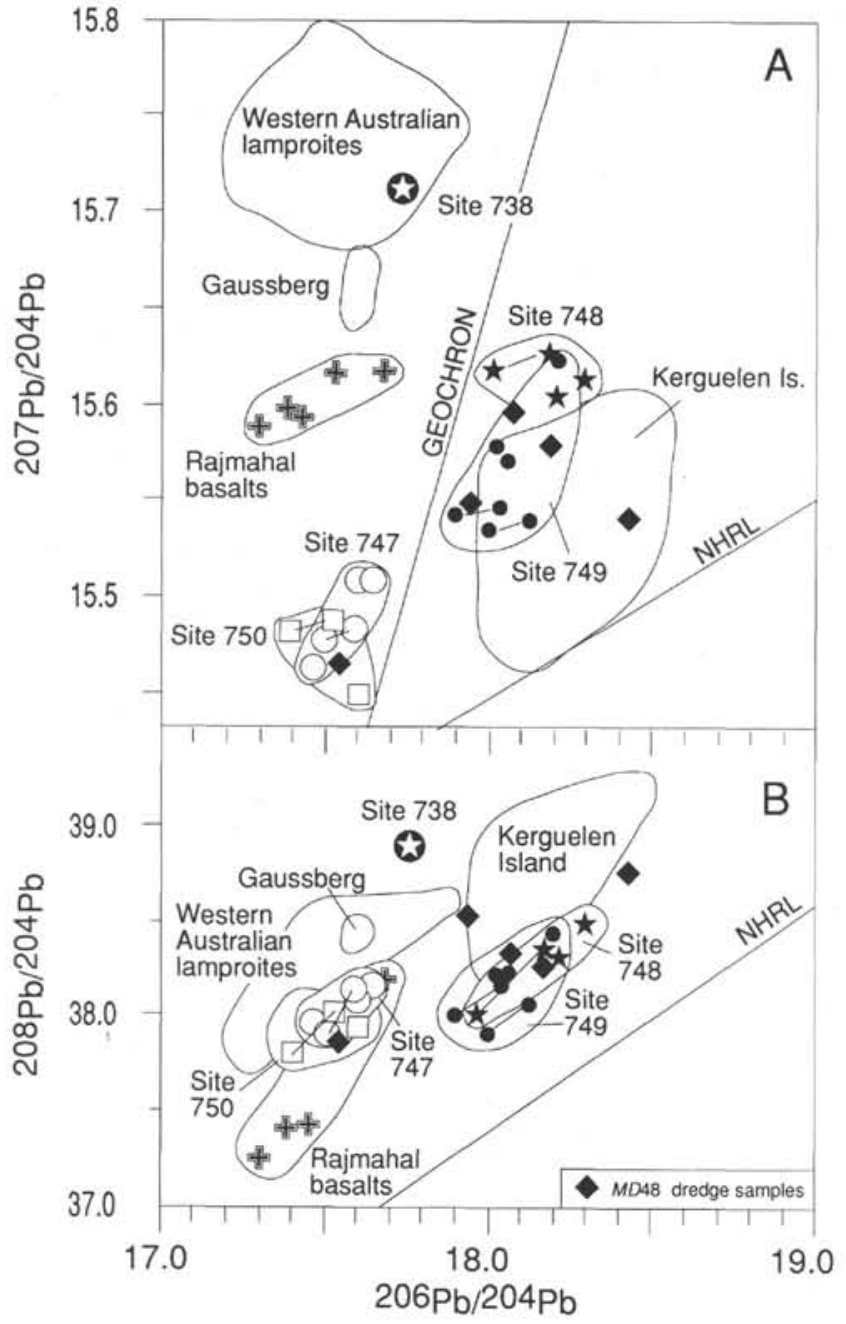

Figure 12. ${ }^{206} \mathrm{~Pb} /{ }^{204} \mathrm{~Pb}$ vs. (A) ${ }^{207} \mathrm{~Pb} /{ }^{204} \mathrm{~Pb}$ and (B) ${ }^{208} \mathrm{~Pb} /{ }^{204} \mathrm{~Pb}$ for Kerguelen Plateau and Rajmahal Trap tholeiites (data from Weis et al., 1989; Alibert, 1991; Salters et al., this volume; M. Storey, unpubl. data). Lines joining points represent the age correction for samples on which $\mathrm{U}$ and $\mathrm{Pb}$ were determined by isotope dilution. Fields for western Australian lamproites and Gaussberg leucitites from Nelson et al. (1986); field for Kerguelen Island basalts field from Dosso et al. (1979), Storey et al. (1988), and Gautier et al. (1990). NHRL = Northern Hemisphere Reference Line (Hart, 1984).

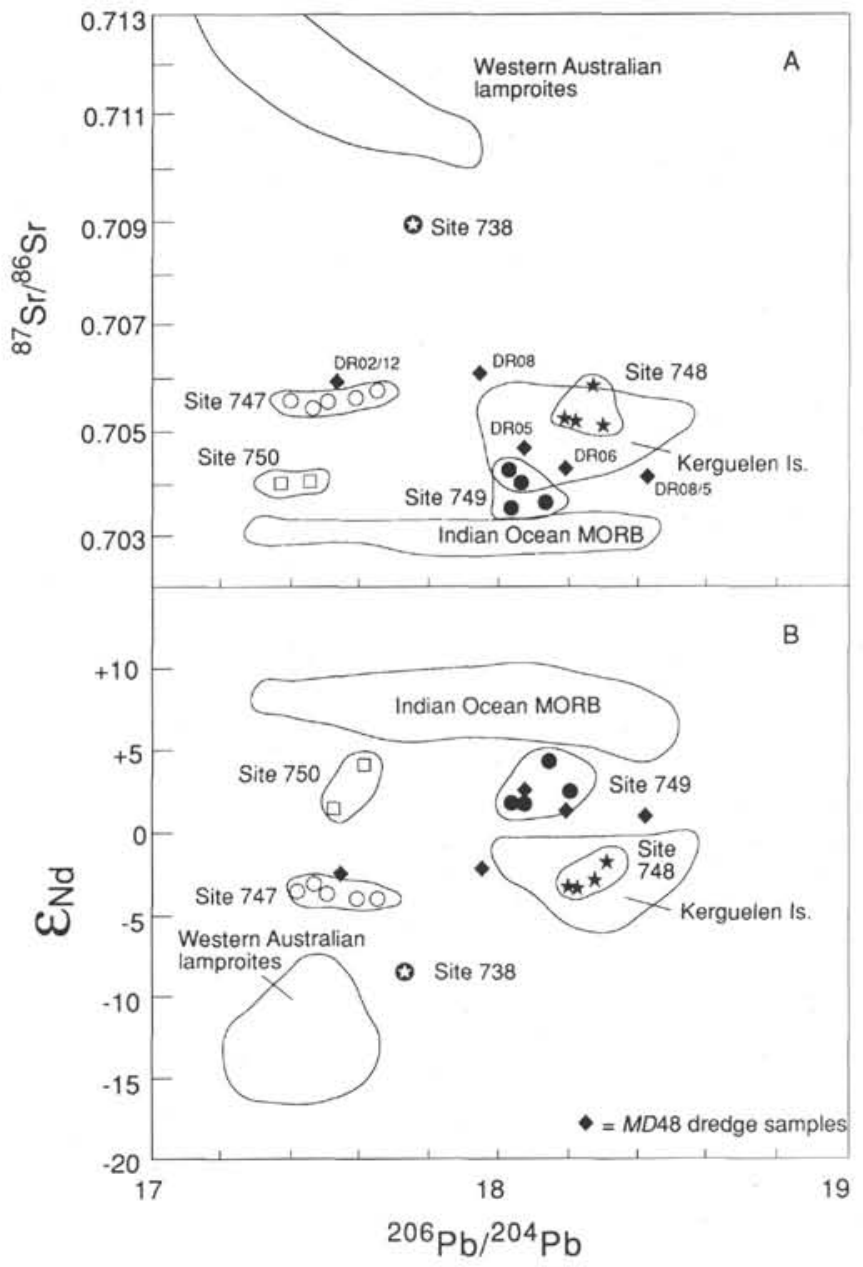

Figure 13. ${ }^{206} \mathrm{~Pb} / 204 \mathrm{~Pb}$ vs. (A) ${ }^{87} \mathrm{Sr} /{ }^{86} \mathrm{Sr}$ and (B) $\varepsilon_{\mathrm{Nd}}$ for Kerguelen Plateau tholeiites. Sources of data are the same as for Figures 11 and 12.

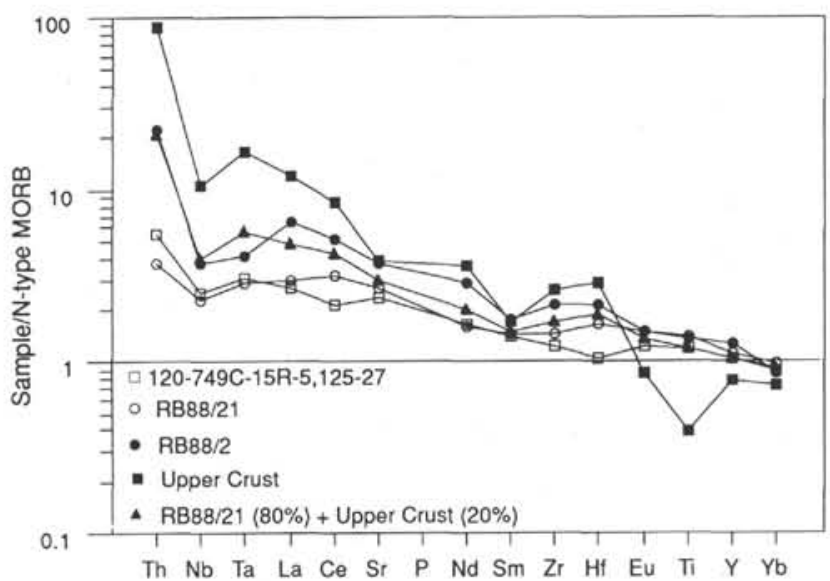

Figure 14. Comparison between MORB-normalized incompatible element plots for Group I Rajmahal tholeiite (RB 88/21) and Site 749 Kerguelen Plateau tholeiite. The addition of $20 \%$ of material with upper-crust composition (from Taylor and McLennan, 1985) to Group I Rajmahal tholeiite mimics incompatible element abundances of the Group II Rajmahal tholeiite illustrated (RB 88/2). 